\title{
RYBNÍK JAKO SOUČÁST HOSPODÁŘSTVÍ VRCHNOSTENSKÉHO PANSTVÍ A INDIKÁTOR PODOBY KRAJINY JIŽNÍHO VALAŠSKA V 15. Ǎ̌ 17. STOLETÍ
}

\author{
JAN PETŘÍK - MICHAL HLAVICA - LIBOR PETR - TOMÁŠ CHMELA - ZDENĚK \\ SCHENK - HANA LUKŠÍKOVÁ - PETER MILO - RADIM VRLA - PETR ODEHNAL - \\ ZDENĚK PETRŮJ - MARTIN PETRŮJ - PETR KOČÁR
}

\begin{abstract}
Abstrakt: Součástí hospodářského rozvoje v kontinentálni Evropě 14. až 16. století bylo rozširení rybníků. $V$ některých regionech se chov ryb stal jednou z hlavnich podnikatelských aktivit šlechty. V̌́eských zemich známe dodnes existujici díla středověkých rybnikář̉o především z jižních a východních Čech. Zajímavé doklady těchto aktivit však byly zaznamenány i v oblasti jihovýchodní Moravy, kde dnes již neexistující rybniky podstatně změnily podobu hospodářství i ráz krajiny někdejšiho brumovského panství. To naznačuji dochované písemné prameny i terénni relikty, jež jsou v dnešni krajině stále ještě více či méně patrné. Archeologický výzkum pozůstatků konkrétního rybničního díla nedaleko obce Mirošova vedl k lokalizaci dobře dochovaných dřevěných prvků sypané hráze, jež datuji jeho založení do obdobi po roce 1488 . V prostoru rybnika, který pravděpodobně zanikl narušením hráze svahovým sesuvem po roce 1536, byly také zaznamenány zbytky vodní a segetální vegetace. Jejich paleoekologická analýza doložila krajinu tvořenou mozaikou lesů, poli a pastvin. Průzkum širšiho okoli pak prokázal napojení hráze na sit’ pozdně středověkých až novověkých úvozových cest a hráz dalšiho rybničního díla. Ta dokládá přitomnost vícestupňové rybniční soustavy.
\end{abstract}

Klíčová slova: rybníkářství-jižní Valašsko - pozdni středověk-časný novověk-paleoekologie.

Fishponds as Economic Components of Aristocratic Estates and Indicators of Landscape Changes in Southern Moravian Wallachia in the 15th-17th Centuries

Abstract: The economic development in continental Europe in the 14th-16th centuries involved the spreading of fishponds, and in some regions fish farming became one of the main economic activities of the aristocracy. In the Czech lands, the works of medieval fishpond designers that still exist today are chiefly known from southern and eastern Bohemia. However, interesting evidence of these activities also comes from south-eastern Moravia where fishponds (that are no longer in existence) substantially changed the form of economy, as well as the character of the landscape on the former Brumov estate. This is further indicated by written sources and terrain relics that are still more or less discernible in the landscape today. Archaeological research into the remains of a particular fishpond near Mirošov brought to light well-preserved timber elements of an earth pond wall, which date its establishment to the period after 1488. The area of the fishpond that probably ceased to exist through the breaking of the wall by a landslide after 1536 yielded the remains of water and marsh vegetation. Their paleoecological analysis revealed a landscape made up of a mosaic of forests, fields and pastures. Research into the wider surroundings of the pond showed a connection between the pond wall and a network of late-medieval and modern-age sunken lanes as well as a wall of another pond, which evidences the existence of a system of fishponds consisting of several levels.

Key words: fish farming - southern Moravian Wallachia-late Middle Ages-early modern age paleoecology.

\section{1 Úvod}

Ve středověku křest’anské Evropy byly ryby důležitou složkou stravy (Hoffmann 1996), v západní Evropě je rozmach rybníkářství kladen již do samého počátku vrcholného středověku (Knowles 1950). Nejstarší doložený rybník v českých zemích je datován podle zakládací listiny kladrubského kláštera do roku 1115, a to i přesto, že až do konce 14. století byly konzumovány spíše ryby z řek, potoků a jezer. S rostoucím počtem obyvatelstva však docházelo $\mathrm{k}$ tomu, že z př́írodních zdrojů nebylo možno zvyšující se poptávku pokrýt, a to zvláště v obdobích půstu. Na přelomu 14. a 15. století se nedostatek ryb začal častěji řešit jejich chovem v umělých vodních nádržích a od tohoto období také můžeme sledovat počátek tradice rybničního hospodářství (Teplý 1937; Míka 1955; Hurt 1960). Dobrým př́ikladem může být rybníkářství na Chrudimsku (viz Teplý 2008). 
Jan Petřík - Michal Hlavica - Libor Petr - Tomáš Chmela - Zdenek Schenk - Hana Lukšíková - Peter Milo - Radim Vrla - Petr Odehnal - Zdeněk Petrůj - Martin Petrůj - Petr Kočár: Rybník jako součást hospodářství vrchnostenského panství a indikátor podoby krajiny jižního Valašska v 15. až 17. století

Ekonomický růst ve 14. až 16. století zapříčinil rozšíření rybníků po celé kontinentální Evropě (Schnitter 1994). Relativně vysoký počet postních dní byl zárukou dobrého odbytu sladkovodních ryb, které na rozdíl od slanečků importovaných z Pobaltí a od Severního moře byly čerstvé a také chutnější. Od druhé poloviny 15. století můžeme rozvoj rybníkářství sledovat i v Čechách, v té době zde došlo $\mathrm{k}$ viditelnému technologickému pokroku. V nově budovaných rybnících se dařilo jedné z nejkvalitnějších a nejžádanějších ryb - kapru. Počet rybníků se prudce zvyšoval již od 70. let 15. století, přičemž předpokladem opravdového tržního úspěchu bylo množství velkých vodních nádrží, jejichž zakládání přicházelo v úvahu především na rozsáhlých panstvích s mokřinami a blaty. Takovými byly východočeské statky Viléma z Pernštejna v Polabí a jihočeské rožmberské državy, zahrnující Třeboňskou i část Českobudějovické pánve (Bartlová-Čornej 2007).

Na Moravě a v Dolním Rakousku se rybníkářská vlna poněkud opozdila. Zatímco v Čechách vrcholilo budování rybníků okolo roku 1500, na Moravě spadá závěr prvního „budovatelského“ období do let 1520 až 1540 (Macek 1992). V Dolním Rakousku došlo k výraznému rozvoji rybníkářství také až v druhé polovině 16. století (Knittler 2005). Rybníkářství, stejně jako zakládání poddanských měst a provozování dolů, je označováno za jednu z nejvýnosnějších aktivit šlechtického podnikání tohoto období. V souvislosti s jeho obrovskou konjunkturou v závěru 15. a v 16. století ( $\mathrm{k}$ tomu viz Vorel 2005) se hovoří o „pravé zakladatelské horečce“, kdy se charakterizuje jako „pravý zlatý důl vrchnostenských důchodü“(Válka 1991). V druhé polovině 16. století byl však trh s rybami v českých zemích již nasycen a rybníkářství začínalo stagnovat. I přes jeho následný úpadek, způsobený především poklesem ceny ryb a postupnými proměnami polního hospodaření, přetrvaly rybniční soustavy v téměř nezměněné podobě až do druhé poloviny 18. století. Počet rybníků klesal s rostoucí potřebou zemědělské půdy, se zintenzivněním obilnářství a pastevectví, jež souviselo s postupným nárůstem počtu obyvatel v pobělohorském období (Bůžek 2010).

Rybníkářství se ve středověku stalo velmi důležitou součástí ekonomiky a v mnoha oblastech nebývalým způsobem změnilo tvář venkovské krajiny. Tisíce vodních nádrží přetvořily i charakter krajiny Čech, Moravy i Slezska. Z historických pramenů máme poměrně jasnou představu o významu chovu ryb od druhé poloviny 15 . století, kdy se prosadila technicky náročná stavba rozlehlých mělkých rybníků s přesně vytyčenými zpevněnými hrázemi. Kromě sypané zeminy byly hráze zpevněny kamením nebo větvemi či dřevěnými rošty. Stavební postupy, technologické preference a jednotlivé součásti rybničních soustav známe z dobových záznamů. Z hlediska poznání konstrukce středověkých rybníků jsou důležité především příručky, které byly napsány v 16. a 17. století (např. Dubravius 1559; souhrnně Aston 1988). Chov kapra v průběhu 16. století se kupř́ikladu opíral o třístupňovou soustavu, tvořenou mělkými plodovými (třecími) rybníky, tzv. výtažníky a rozlehlými hlavními (výrostními) rybníky. Ty byly spojeny soustavou kanálů nebo potrubí. Rybníky se tak staly zároveň umělým dílem i přírodním prostředím (Knittler 2005). S touto skutečností souvisí badatelsky dosud nepř́iliš vytěžený fakt, že umělá vodní nádrž je během své existence i po svém zániku ovlivňována změnami krajiny a uchovává záznam o její historické podobě.

Metodika archeologického výzkumu rybníků a některé konstrukční detaily diskutují R. A. Chambers a M. Grayová (1988), kteří čerpají především z výzkumu rybničního díla v obci Thame (hrabství Oxfordshire, Velká Británie). Zde R. A. Chambers provedl archeologickou dokumentaci soustavy tř́ rybníků s dřevěným vypouštěcím zařízením vytesaným z jilmu (viz také Chambers 1975). ${ }^{1}$ Úzké propojení mezi archeologií středověkých rybníků a zájmem o historii krajiny je patrné na výzkumu v anglickém hrabství Worcestershire, ${ }^{2}$ zohledněno bylo i v rámci některých tuzemských výzkumů. Při nich se podobně jako ve Velké Británii (viz ShackleyHayne-Wainwright 1988) podařilo využít sedimenty zaniklých středověkých umělých nádrží

1 Zaniklé středověké až časně novověké rybníky však již byly archeologicky zkoumány i na území České republiky, především prostřednictvím záchranných archeologických výzkumů (Staroměstský rybník v Telči, Markvartický rybník v Jablonném v Podještědí, rybník Jordán u Tábora). Výzkumy však dosud nebyly patřičně publikovány.

2 Worcestershire Archaeological Service: Ponds and Archaeology, Fact Sheet No. 8. Dostupné z: http://www.adlib.ac.uk/resources/000/091/004/ cs-archeo-fact_sheet_8.pdf. 
k rekonstrukci přírodního prostředí (Jankovská-Pokorný 2002; Pokorná a kol. 2014). Terénní výzkum kombinující archeologické, geomorfologické a paleoekologické postupy tedy podstatným způsobem napomáhá doplňovat obraz poskytnutý písemnými prameny.

Cílem této studie je, podobně jako v př́ípadech uvedených výše, poznání role rybníkářství v regionální ekonomice, rekonstrukce užité technologie chovu ryb a také analýza environmentálního záznamu, jenž se v sedimentech rybníka dochoval z konce středověku a počátku novověku. Problém je zkoumán v různých prostorových měřítkách od ekonomiky a regionální historie vrchnostenského panství přes vyhodnocení středověkých a časně novověkých terénních reliktů a archeologických nálezů z vybraného úseku krajiny až po technologická specifika konkrétního archeologicky zkoumaného rybničního díla. Prostřednictvím výzkumu sedimentární výplně se také pokoušíme rekonstruovat stav krajiny jižního Valašska $v$ neklidných časech na přelomu stř̌edověku a novověku. Vytyčené cíle jsou naplňovány prostřednictvím rešerše písemných pramenů o hospodaření na brumovském panství společně s archeologickým vyhodnocením dosud neznámého zaniklého rybníka na katastru obce Mirošov.

\section{Regionální historie a charakteristika území}

\subsection{Hospodaření vrchnosti na brumovském panství}

Důležitým pramenem zachycujícím vrchnostenské hospodaření na někdejším brumovském panství je velmi cenný dokument vyhotovený roku 1662 v souvislosti s dělením panství po smrti hraběnky Ester Forgáčové. ${ }^{3}$ Tento výčet majetku je vhodným pramenem nejen k rekonstrukci ekonomického fungování panství, ale i k pochopení role regionálního rybníkářství na přelomu středověku a novověku. Rovněž je dobrým podkladem pro mapování prostorové distribuce rybníků, jejichž lokalizace může být dále validována metodami dálkového průzkumu země či archeologickými metodami. Pramen mimoto zmiňuje i další hospodářská zařízení na panství Brumov, jako jsou hospodářské dvory, soukenické rámy, mýta, mlýny, valchy, pily, pivovary a lihovary či šenkovní domy (obr. 1).

$\mathrm{V}$ období druhé poloviny 17. století fungovalo $\mathrm{v}$ rámci panství sedm hospodářských dvorů. Největším dvorem byl dvůr brumovský, kde se osévala více než čtvrtina všech obilnin. Šestina až sedmina celkového podílu pak náleží třem velikostně srovnatelným dvorům v Haluzicích, Mirošově a Vlachovicích. Vedle dalších hospodářských zařízení je dokumentována také existence dvaceti šesti rybníků, z nichž ovšem polovina byla v této době již pustých. Mezi stále funkční rybníky patřilo dílo v Bohuslavicích, tři rybníky v Brumově (pod hradem), jeden v Horní Lidči, dva u Jestřabí, jeden pod Lačnovem, jeden pod Lhotou, jeden v Popově, dva ve Vlachovicích (jeden z nich pod Kaštýlem) a jeden ve Vukouní. ${ }^{5}$ Za pusté rybníky můžeme označit dílo pod Kamenicí, v Horní Lidči a Lidečku, dva rybníky v Mirošově (,zwey öede Teicht unter Miroschaur"), jeden v Popově, Poteči a Př́́kazech, dva ve Střelné, jeden ve Vlachovicích, na Vláře a ve Vukouní. Modernější tř́stupňovou soustavu lze předpokládat pouze $\mathrm{v}$ př́padě trojic rybníků u městeček Brumov a Vlachovice. S ohledem na válečné události 17. století (viz Odehnal 2014) lze předpokládat, že většina rybničních zařízení v oblasti má svůj počátek přinejmenším v 16. století. Válečné události měly na stav rybníků zjevně destruktivní vliv - polovina $\mathrm{z}$ nich byla $\mathrm{k}$ roku 1662 pustá.

\subsection{Majetkové vztahy a první zmínky o rybníkářství na brumovském panství}

Ladislav Podmanický z Podmanína měl v létě roku 1469 postavení nejvyššího hejtmana vojska Matyáše Korvína pro Moravu a jednou z nejzásadnějších odměn za jeho věrné služby byla zástavní držba brumovského panství. Svůj druhý sňatek uzavřel Podmanický s Elenou

\footnotetext{
3 Moravský zemský archiv v Brně, fond A 3 Stavovské rukopisy, inv. č. 295.

4 Dalši dvory jsou v Lačnově, Štítné a Bylnici; soukenický rám (Brumov), čtyři mýta (Klobouky, Bylnice, Nedašov, Střelná), čtyři valchy (mezi Klobouky a Brumovem, v Bylnici, Lidečku a Štítné; výstavba další byla zamýšlena u Klobouk), tři pily (Bylnice a dvě v Lidečku), devět mlýnů (Bohuslavice, Brumov, Bylnice, Horní Lideč, Klobouky - horní a dolní mlýn, Lidečko, Štítná, Vlachovice), dva pivovary a lihovary (Brumov, Vlachovice) a pět šenkovních domů (Brumov, Bylnice, Polanka, Újezd, Vlachovice).

5 „Wukauni“, ,Wukhauni“, pravděpodobně trat' Rybničiska v jižní části katastru obce Újezd.
} 


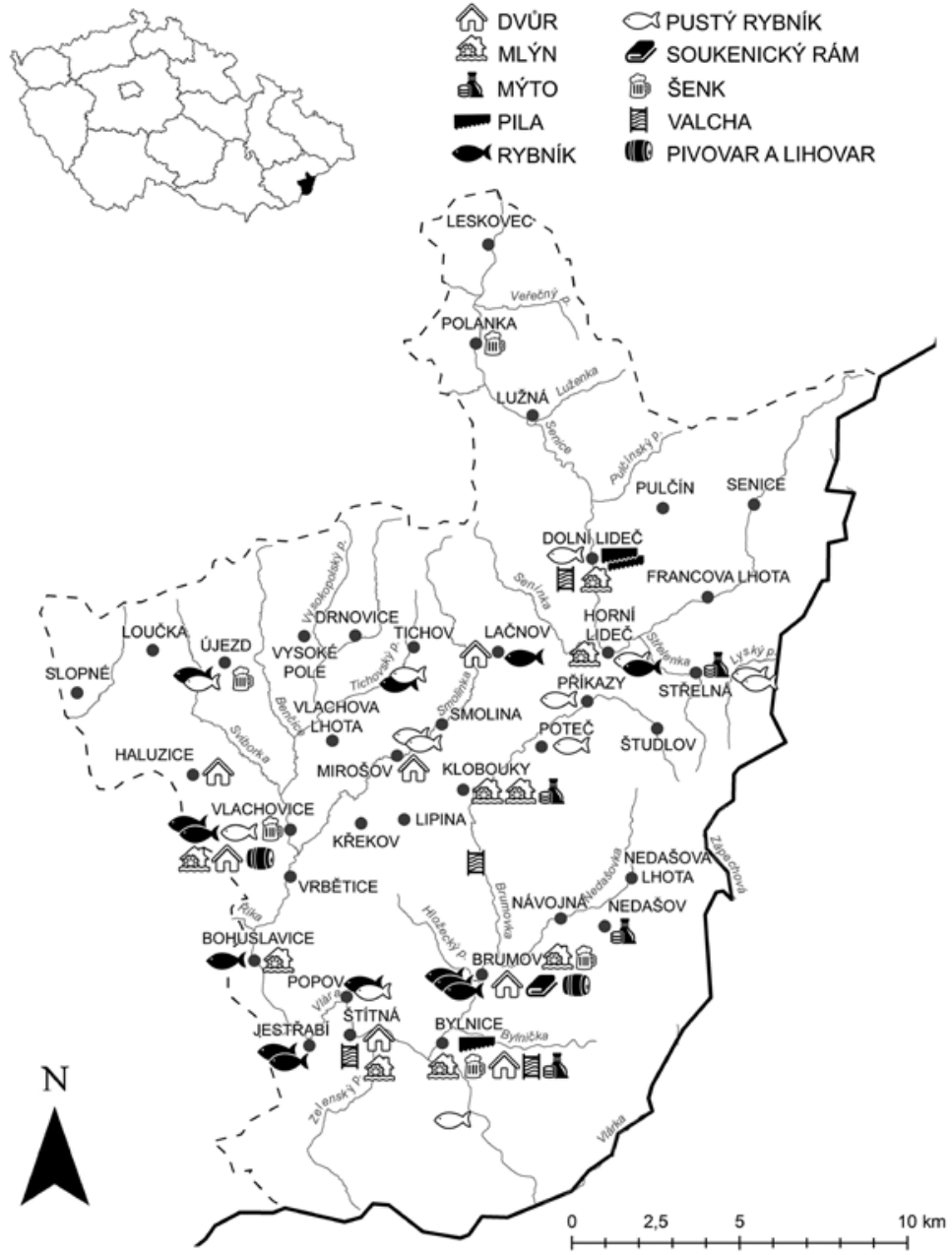

Obr. 1. Mapa brumovského panství s hospodářsky významnými provozy k roku 1662.

Abb. 1. Karte der Grundherrschaft Brumov mit bedeutenden Wirtschaftsbetrieben zum Jahr 1662.

Országovou, dcerou uherského palatina. Po jeho smrti (zemřel zřejmě roku 1488) se o brumovský majetek starala vdova Elena a synové Michal a Štěpán. Vrchní vlastnická práva měl nicméně stále ve svých rukou panovník. Král Vladislav se ale záhy svých práv zřekl a postoupil je - někdy těsně před rokem 1500 - Janu Meziříčskému z Lomnice, toho času moravskému zemskému hejtmanovi. Ten začal podnikat kroky směřující k vyplacení panství k dědičné držbě. Bratři Podmaničtí ale nakonec od Jana Meziř́íčského právo vyplatit zástavu odkoupili. Status Brumova jako královského majetku zanikl a Podmaničtí získali plná práva k dědičnému vlastnictví panství. Král Vladislav vše potvrdil v prosinci 1503.

Roku 1511 se Michal Podmanický zřekl své držby a spoluvlastníkem Brumova se stal jeho švagr Jiř́ík Tarczy z Torysy, kterému roku 1515 postoupil svá práva i Štěpán Podmanický, a Tarczy se tak stal jediným držitelem panství. Nedařilo se mu však, byl zasypán dluhy a různými žalobami, až v lednu roku 1518 přenechal brumovský majetek Michalovi Podmanickému. Ten ho obratem prodal Janu z Lomnice (Pokluda 1999). 
S pány z Lomnice jsou spojeny nejstarší zprávy vztahující se k rybníkářství na brumovském panství. Významný a zámožný šlechtic Jan z Lomnice, který koupil panství Brumov někdy počátkem roku 1519, na panství prosazoval účinnější formy hospodaření využíváním pastvin. Z jedné zmínky se dozvídáme, že poddaní z Lidečka vedli spor o „stádo ovec a koz valaských“ (1528), a jakási souvislost s novým „,valašským“ pastevectvím se asi pojí i se jménem Jana Bubeníka, ,syna Valachova“ (1539). Jan z Lomnice zemřel roku 1533, panství zdědil Adam z Lomnice, který se intenzivně zaměřil na správu svého hlavního majetku. Mimo jiné panství rozšíríil prrikoupením tří vsí (kolem roku 1545) a jak uvádí Z. Pokluda (2005), „staral se o větši výnos panství zřizováním rybnikủ, jak napovídá jedna zmínka (1538), a také zveleboval své brumovské sidlo“. Pokluda čerpá z edice Františka Kameníčka (1902), přičemž se však v dataci dopouští nepřesnosti. Adam z Lomnice dal totiž na svém panství budovat rybník a podle zprávy z roku 1539 (tamtéž, 403) lidé jeho uherského souseda Podmanického ,pobili některé rybnikáře, jiné

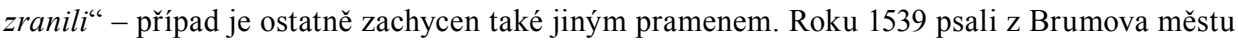
Trnava o práci jistého M. Rohlíka ve službách pána z Lomnice „na stavbě rybníků na Vláře“ a o tom, že lidé pana Podmanického tyto práce přerušili (Macůrek-Rejnuš 1958, 42).

Budování rybniční sítě na brumovském panství dokumentuje i Zdeněk Kavka z Říčan, který od Jana Vince ze Seredi roku 1573 odkoupil vlastnická práva ke vsi Mirošov, mirošovský dvůr dále rozvíjel, rozšířil a př́ipojil k němu i některé pozemky klobouckých hospodářù (Odehnal 2000). Dne 19. července roku 1577 psal do Trnavy: „Před vámi netajím, že nějací rybnikáři tu na panství mém broumovském mně nějaký dilo dělali a po vykonání toho díla odtud pryč sou se odebrali.“(Macůrek-Rejnuš 1958, 239).

Na základě studia dochovaných písemných pramenů lze tedy konstatovat, že ve sledované oblasti někdejšího brumovského panství byly v průběhu 15. a 16. století prokazatelně zakládány a provozovány četné rybníky u mnoha tehdejších vsí. Mezi nimi byla i dvě díla na katastru obce Mirošov, jež však byla k roku 1662 již obě pustá.

\section{Výzkum rybničního díla na katastru obce Mirošov}

Lokalita s pomístním názvem Rybníčky se nachází na katastrálním území obce Mirošov v blízkosti k. ú. Smolina (obě obce jsou místními částmi města Valašské Klobouky) v úzkém bočním údolí (obr. 2), odkud vtéká bezejmenná vodoteč do potoka Smolinky (ten se u Vlachovic vlévá do Vláry, zdrojnice Váhu). Povodí Smolinky se nachází na rozhraní Bílých Karpat a Vizovické vrchoviny v oblasti Slovensko-moravských Karpat. Archeologické relikty na lokalitě byly poprvé zaznamenány $\mathrm{v}$ roce 2011 při sledování melioračních prací na pozemcích obhospodařovaných Zdeňkem Petrůjem. V roce 2012 při pokračování odvodňování zde proběhl záchranný archeologický výzkum ve spolupráci s Muzeem jihovýchodní Moravy ve Zlíně, a to zejména v prostoru hlavní meliorační rýhy, která narušila některé dřevěné konstrukce později odhalené rybniční hráze. Archeologický odkryv se soustředil na několik hlavních řezů při použití kresebných dokumentačních metod a následného georeferencování terénní dokumentace v prostředí GIS. Součástí vyhodnocení širšího okolí rybníka byla i analýza podrobného modelu reliéfu, který byl vytvořen na základě zpoplatněných dat digitálního výškopisu 5. generace (DMR 5G) distribuovaných ČÚZK. Vzorky pro dendrochronologické datování (vyhodnotil T. Kyncl) byly odebrány řezem z okrajových částí dřevěných prvků, po průzkumu a dokumentaci byly tyto prvky ponechány pod zemí a zasypány vytěženou zeminou.

Ke geofyzikálnímu měření bližšího okolí byl použit magnetometr Fluxgate Foerster Ferex 4.032 DLG od společnosti Förster a georadar RAMAC X3M značky Malå. Magnetické měření se uskutečnilo v rastru $0,25 \times 0,50 \mathrm{~m}$. Na zkoumaném území, kde se $\mathrm{v}$ době průzkumu stále nacházela částečně zasypaná odvodňovací rýha s podélným pásem vykopané zeminy, byl vytyčen areál o rozloze $18700 \mathrm{~m}^{2}(\mathrm{ca} 70 \times 275 \mathrm{~m}$ ). Pro účely georadarového průzkumu byly využity stíněné antény s frekvencí 500 a $250 \mathrm{MHz}$ s předpokládaným hloubkovým dosahem $1 \mathrm{až} 3 \mathrm{~m}$, resp. 3 až $6 \mathrm{~m}$. Na ploše bylo proměřeno šest profilů o celkové délce $821 \mathrm{~m} \mathrm{~s}$ každou anténou. 


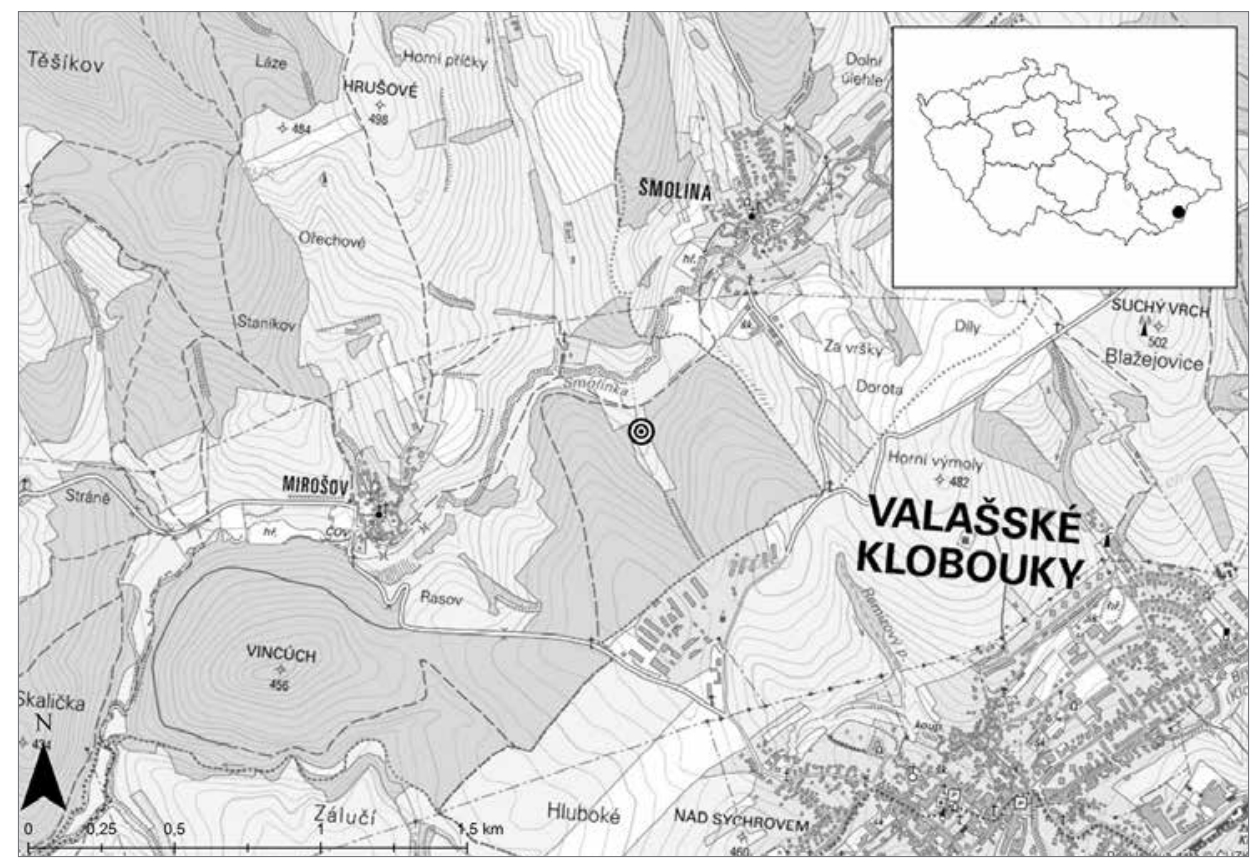

Obr. 2. Lokalizace zkoumaného území.

Abb. 2. Lokalisierung des untersuchten Gebietes.

Linie průzkumu byly orientovány podle konfigurace terénu a na základě předchozích výsledků magnetického průzkumu, přičemž přetínaly celou dostupnou plochu ve směru severozápad-jihovýchod a jihozápad-severovýchod.

Vzorky sedimentu byly odebrány z vertikálních profilů exkavovaných sond $\mathrm{v}$ deseticentimetrových intervalech. Zrnitostní distribuce byla stanovena laserovou granulometrií na př́stroji Cilas 1190. Vzorky byly dispergovány v KOH a organická hmota byla odstraněna reakcí s $\mathrm{H} 2 \mathrm{O} 2$. Měřena byla také ztráta hmotnosti žíháním (LOI) při teplotě $550{ }^{\circ} \mathrm{C}$ (reprezentuje především organickou hmotu) standardní metodou (Heiri et al. 2001). Měření magnetické susceptibility (MS) vysušených vzorků o hmotnosti $23 \mathrm{~g}$ bylo realizováno v Laboratoři geologických procesů (GLÚ AV ČR, v. v. i.) pomocí př́stroje Kappabridge KLY 2 (Agico, s. r. o.). Pro vynesení dat byla použita nenormalizovaná hmotnostní MS vyjádřená $\mathrm{v} \mathrm{m}^{3} \cdot \mathrm{kg}^{-1} \times 10^{-9} \mathrm{~s}$ chybou měření pro každý vzorek $\pm 2 \%$.

Na pylovou analýzu byl odebrán přibližně $1 \mathrm{~cm}^{3}$ sedimentu. Povrchový vzorek (odpovídající v pylovém diagramu hloubce $0 \mathrm{~cm}$ ) odebraný na lokalitě $\mathrm{z}$ trsů trávy a mechových polštářů byl dva dny odmočen ve vodě a sedimentovaný materiál byl dále zpracován. Zpracování palynologických vzorků bylo provedeno standardní acetylační metodou, včetně použití kyseliny fluorovodíkové na odstranění křemičitanů. Determinace pylových zrn byla provedena s použitím palynologických klíčů (Beug 2004; Moore et al. 1999). Napočítaná suma pylových zrn byla minimálně $500 \mathrm{ks}$. Pylový diagram byl proveden v programu POLPAL (Walanus-Nalepka 2003), přičemž pyly olše (Alnus) a ostřic (Cyperaceae) byly vyloučeny z celkové sumy.

Makrozbytky byly plaveny mokrým proséváním a uloženy ve vodě. Separace a identifikace byla provedena pod stereomikroskopem s 16-70násobným zvětšením. Určovány byly pomocí atlasů (Berggren 1981; Bojňanský-Fargašová 2007; Cappers et al. 2006; Katz et al. 1965) a srovnávací sbírky. 


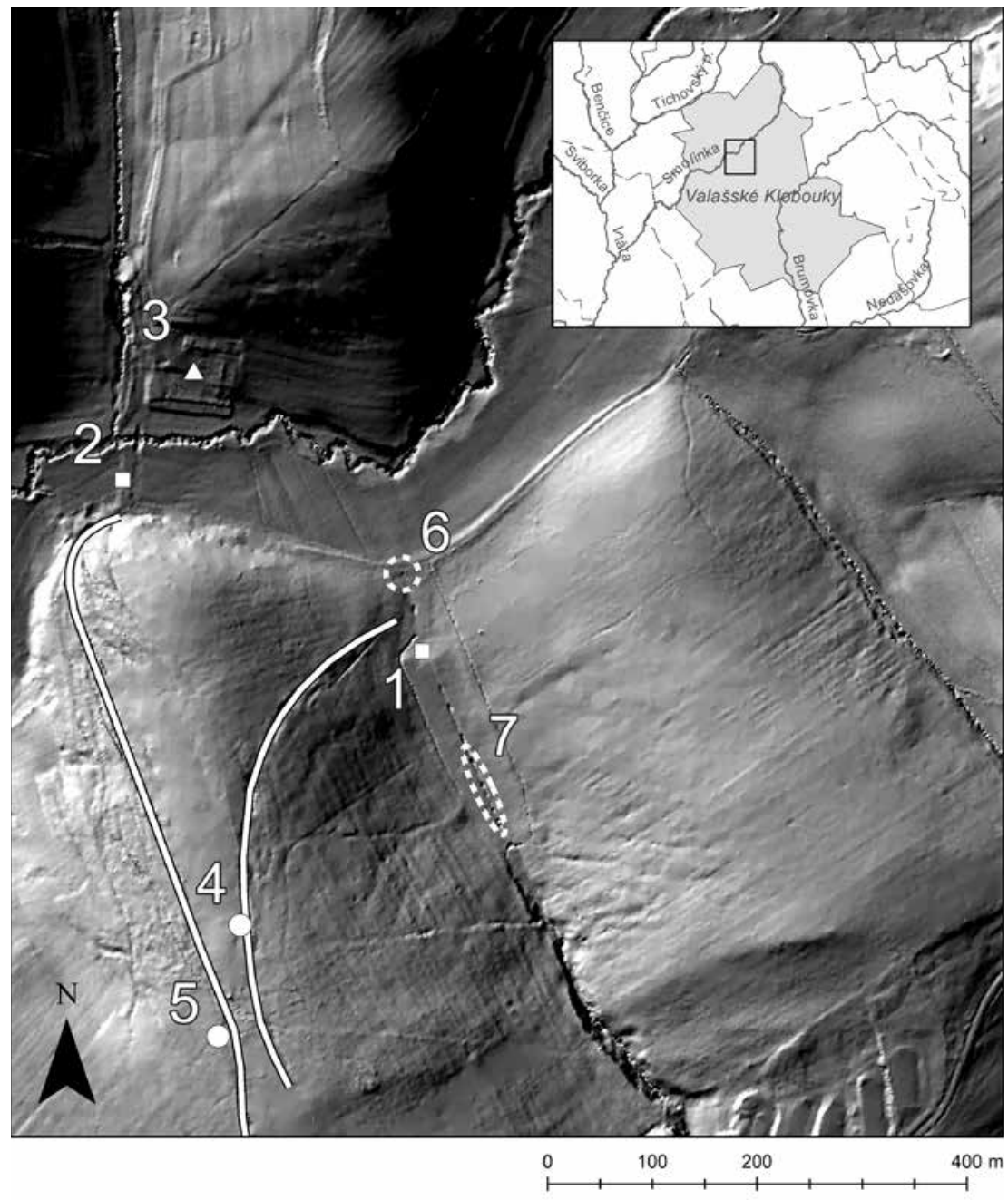

Obr. 3. Stínovaný digitální model reliéfu (vytvořený na základě dat LiDAR) zájmového území s vyznačenými středověkými a novověkými terénními relikty. 1 - hráz zkoumaného zaniklého rybníka, 2 - hráz zaniklého rybníka, 3 - hospodářský dvůr, 4, 5 - detektorové nálezy z kontextu prozkoumaných úvozových cest - mince, podkova, 6 - koncentrace středověké keramiky v prostoru „mezi hrází a začátkem údolí“, 7 - koncentrace stř̌edověké keramiky v prostoru „nad rybníkem proti proudu vodoteče“.

Abb. 3. Schattiertes digitales Modell des Reliefs (erstellt anhand von LiDAR-Daten) des Interessengebietes mit eingezeichneten mittelalterlichen und neuzeitlichen Geländerelikten. 1 - Damm des untersuchten verschwundenen Teiches, 2 - Damm eines verschwundenen Teiches, 3 - Wirtschaftshof, 4, 5 - per Detektorsuche im Kontext der untersuchten Hohlwege entdeckte Funde - Münze, Hufeisen, 6 - Konzentration mittelalterlicher Keramik im Bereich „zwischen Damm und Anfang des Tals“, 7 - Konzentration mittelalterlicher Keramik im Bereich „oberhalb eines Teiches stromaufwärts“.

Zlomky dřeva byly analyzovány pomocí světelného mikroskopu upraveného pro pozorování v dopadajícím světle (episkopický mikroskop). Po provedení čerstvých lomných ploch (transverzální, radiální a tangenciální zlom) byly fragmenty př́ímo prohlíženy při 50-, 100- a 200násobném zvětšení. Determinace proběhla na základě základní srovnávací literatury anatomie dřeva evropských dřevin (Schweingruber 1990a; 1990b). 
Pro datování dubového dřeva byla použita standardní chronologie dubu pro Moravu moges (Kolář 2012), jedle byla datována pomocí standardní chronologie pro Moravu je-mo05 (Kyncl nepubl.) a standardní chronologie pro jižní Polsko 3ABSP1 (Krapiec nepubl.). Śírky letokruhů byly změřeny pomocí zařízení Timetable s neznačkovým stereomikroskopem (zvětšení 10-40krát). Parametry synchronní pozice: je-mo05 x S90smolina-rybnikAB tBP 3,76; tHO 4,89; Gl 64,4\%; n 59; r 0,49; 3ABSP1 x S90smolina-rybnikAB tBP 4,06; tHO 5,59; Gl 67,8\%; n 59; r 0,65 mo-ges07 x S9002 tBP 6,19; tHO 6,2; Gl 69,4\%; n 170; r 0,42. Hodnoty t-testu korelačního koeficientu po standardizaci letokruhových řad pomocí pětiletého klouzavého průměru (tBP) a metodou popisovanou Hollsteinem (1980; tHO). Dále je uvedena hodnota koeficientu souběžnosti (GI), délka překrytí srovnávaných letokruhových řad (n) a hodnota korelačního koeficientu (r) vypočítaná pomocí programu Cofecha.

\section{Výsledky}

\subsection{Topografie středověkých a časně novověkých terénních reliktů a archeologické nálezy}

Relikty hrází zaniklých rybníků jsou v prostoru potoka Smolinka a jeho bezejmenného př́itoku dosud patrné jako nevýrazné terénní hrany, jež jsou viditelné i na digitálním modelu reliéfu vytvořeném z dat LiDAR (obr. 3). V mapovém výřezu je rovněž patrná sít' úvozů směřujících z Valašských Klobouk do údolí potoka Smolinky (obr. 3:4, 5). Nad údolím se úvozy větví, přičemž jeden $\mathrm{z}$ nich směřuje $\mathrm{k}$ předpokládanému tělesu zkoumané hráze ve vedlejším údolí (obr. 3:1). Druhý úvoz míří k hrázi v údolí Smolinky, kde se nachází novověký hospodářský dvůr (obr. 3:3) a pravděpodobně další hráz rybníka (obr. 3:2). Na modelu reliéfu je dále vymezen prostor s nálezy keramiky (obr. 3:6 a 7). Na základě dat LiDAR tedy byla na katastru Mirošova zjištěna přítomnost dvou rybničních hrází, což koresponduje s počtem rybníků uvedeným v listině z roku 1662.

V rámci rekognoskace terénu v okolí místa výzkumu rybničního díla byl proveden preventivní detektorový průzkum části úvozové cesty. ${ }^{6}$ Jednalo se o úsek staré cesty stáčející se ze strany západní do prostoru, kde se nacházela archeologicky doložená sypaná hráz rybníka. Během detektorového průzkumu byly zajištěny dva kovové předměty. V prvním př́ípadě se jedná o železnou tzv. „,volskou podkovu“, kterou lze rámcově datovat do postmedieválního období.

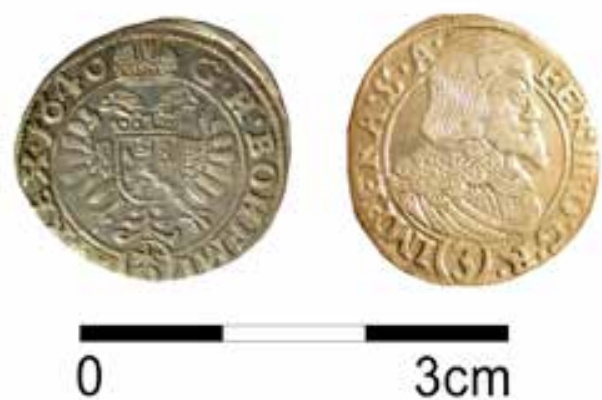

Obr. 4. Stř́íbrný tř́íkrejcar Ferdinanda III. (1637-1657) z roku 1640 nalezený v úvozu vedoucím k hrázi rybníka. Abb. 4. In einem zum Teichdamm führenden Hohlweg gefundene Dreikreuzer-Silbermünze von Ferdinand III. (1637-1657) aus dem Jahr 1640.
Ve druhém případě se jedná o chronologicky podstatně citlivější nález - je jím stříbrný tř́ikrejcar Ferdinanda III. (1637-1657) z roku 1640 , ražený v mincovně Jakuba Bernarda Wolkera v $\operatorname{Praze}^{7}$ (obr. 4). Tento solitérní nález lze vysvětlit aktivitami probíhajícími před polovinou 17. století, tedy pravděpodobně v období intenzivnějšího využivání komunikace vedoucí z údolí Smolinky směrem do města Valašské Klobouky.

\subsection{Geofyzikální průzkum}

$\mathrm{Na}$ ploše zkoumaného areálu byly detekovány magnetické anomálie různého charakteru (obr. 5:A). K nejvýraznějším patří kruhové anomálie s vysokými magnetickými hodnotami (od $100 \mathrm{nT}$ do 300 nT) indikující

\footnotetext{
6 Prospekce byla realizována dne 30. 7. 2016 za pomoci detektoru kovů značky XP Deus V3.2 PRO. V současné době se jedná o zalesněný prostor (parc. č. 514/1 a 513/1 v k. ú. Mirošov) ohraničující ze západní strany úzké boční údolí, kterým protéká bezejmenný levostranný př́tok potoka Smolinka. Nálezy jsou uloženy v Muzeu jihovýchodní Moravy ve Zlíně.

7 Ferdinand III. (1637-1657); mincovna: Praha, mm. Jakub Bernard Wolker (1637-1655), AR 3krejcar 1640; av.: FER.III.D.G.R. (3) IMPERA. S. A.; rv.: G.H.BOHEMI (ruka s hvězdou) Æ. REX.1640; lit.: Halačka 1988, 573, jako číslo 1181; rozměry: 1,1 g; $19 / 20$ mm; místo nálezu: na parc. č. 514/1 (v okolí bodu 4908 55,58 N; 1759 22,18 E, WGS 84); uloženo: Muzeum jihovýchodní Moravy ve Zlíně.
} 

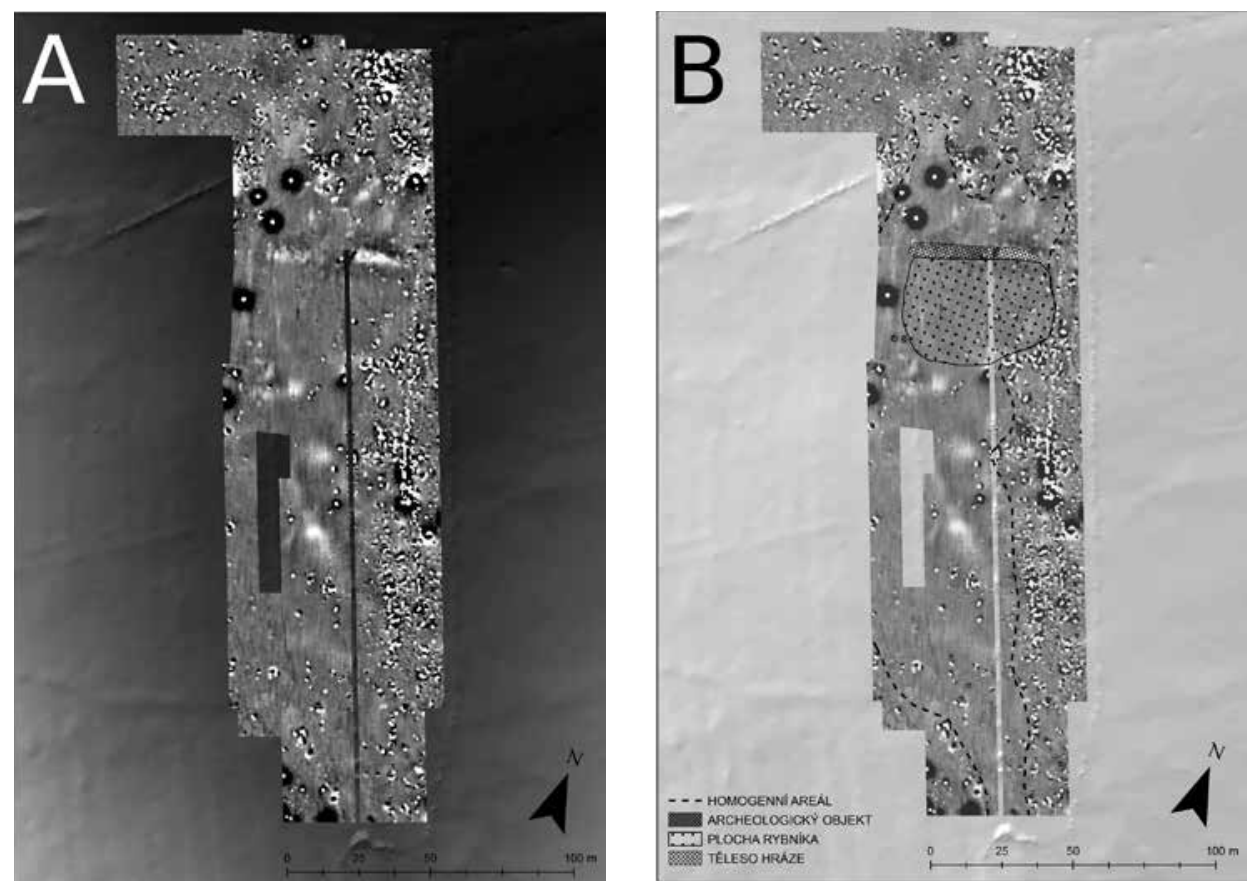

Obr. 5. Magnetogram (Foerster Ferex, -2/2 nT, černá/bílá) zaniklého rybníka a blízkého okolí (A) s vloženými interpretacemi magnetických anomálií (B).

Abb. 5. Magnetogramm (Foerster Ferex, $-2 / 2$ nT, schwarz/weiß) des verschwundenen Teiches und der nahen Umgebung (A) mit eingefügten Interpretationen der magnetischen Anomalien (B).

přítomnost kovových tyčových předmětů pod povrchem. Zřejmě se jedná o starší, již nepoužívaný odvodňovací systém. Celkem jich bylo na ploše průzkumu lokalizováno třináct. Čtyři z nich se nacházejí při západním okraji zkoumané plochy bezprostředně vedle nebo př́imo na lineární struktuře starší, již zasypané rýhy. Ta se v magnetických datech projevila jako mírně pozitivní liniová struktura s hodnotami do ca $0,7 \mathrm{nT}$. Časově a funkčně spolu mohou souviset. Recentní meliorační rýha $-\mathrm{v}$ době průzkumu částečně otevřená - se na magnetogramu projevila jako negativní magnetická lineární struktura s hodnotami ca $-0,4$ nT. Poslední skupinu v rámci recentních objektů představují drobné magnetické dipóly - anomálie s plusovými a minusovými magnetickými hodnotami od ca -30 do 100 nT. Jde o drobné metalické předměty nacházející se v horních vrstvách terénu nebo přímo na povrchu. Často se jedná o drobný odpad. U některých se však může jednat také o drobné kovové předměty nerecentního stáří. Rozptýlené jsou téměř výhradně v severní a východní části magnetogramu. V centrální a jižní části zkoumané plochy se vyskytují pouze ojediněle, což může souviset s přítomností vodní hladiny zamezující ukládání a ztrácení kovových předmětů, případně se subrecentním přemístěním zeminy do prostoru bývalého rybníka. Část lokalizovaných dipólů souvisí s novověkými činnostmi. Další část může souviset s historickými aktivitami, které byly v bezprostřední blízkosti rybníka realizovány.

Menší počet anomálií s magnetickými hodnotami od ca 3 do 10 nT může ukazovat na zahloubené archeologické objekty. Tyto anomálie se koncentrují především východně a severně od plochy rybníka a poměrně vysoké magnetické hodnoty u některých z nich by mohly indikovat přepálené vrstvy nebo výplně bohaté na organické složky. Bližší charakter, jakož i datace těchto struktur je ale nejasná. Nejasný je i charakter dalších drobných anomálií, které se v těchto místech nacházejí. Obě skupiny však dokládají antropogenní aktivity u břehů rybníka a vymezují 
Jan Petřík - Michal Hlavica - Libor Petr - Tomáš Chmela - Zdenek Schenk - Hana Lukšíková - Peter Milo - Radim Vrla - Petr Odehnal - Zdeněk Petrůj - Martin Petrůj - Petr Kočár: Rybník jako součást hospodářství vrchnostenského panství a indikátor podoby krajiny jižního Valašska v 15. až 17. století

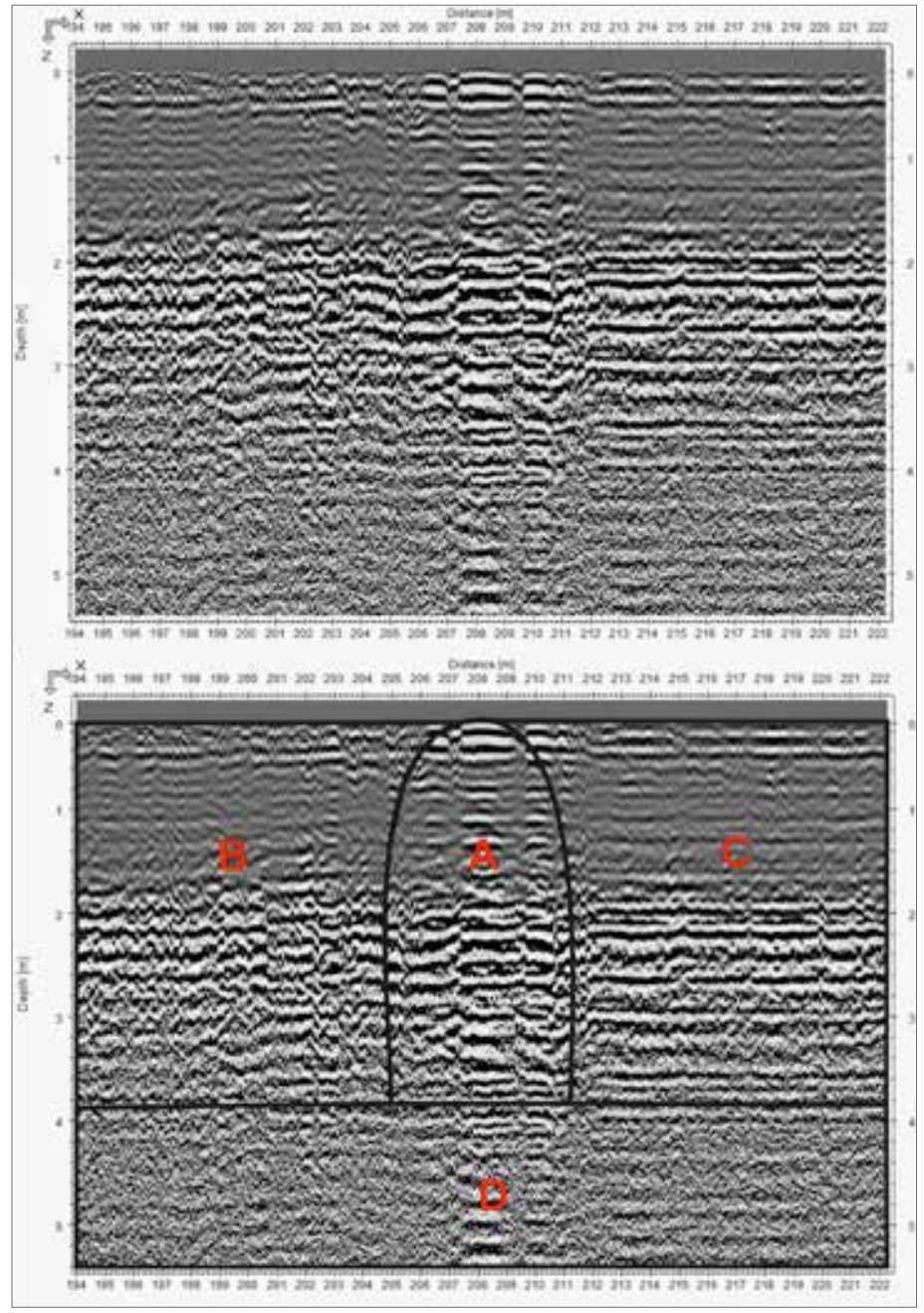

Obr. 6. Radarogram (Malå, 500 Mhz anténa) a jeho interpretace (dole). A - rybniční hráze, B - sedimenty uvnitř rybníka, C - plocha před hrází, D - geologické podloží.

Abb. 6. Radarogramm (Malå, 500 Mhz-Antenne) und seine Interpretation (unten). A - Teichdamm, B - Sediment im Teich, C - Fläche vor dem Damm, D - geologischer Untergrund.

hlavní areály, v nichž $\mathrm{k}$ těmto aktivitám docházelo. Jejich původ a funkci může v budoucnu upřesnit další archeologický výzkum.

$\mathrm{K}$ nejdůležitějšímu zjištění magnetické prospekce patř́i zaznamenání rozsahu rybniční hráze (obr. 5:B). Těleso hráze se v geofyzikálních datech projevilo jako magneticky poměrně nevýrazná ca 3,5-4 m široká a $50 \mathrm{~m}$ dlouhá lineární struktura probíhající přibližně ve směru východ-západ kolmo na údolní nivu. Měření zde dosahuje hodnot ca 1 až 2 nT. Okolní terén vykazuje magnetické hodnoty v rozmezí 0,05 až $0,5 \mathrm{nT}$. Nízké hodnoty v oblasti hráze poukazují na absenci kamenných nebo jiných cizorodých prvků v tělese valu. Jedná se tedy výhradně o místní materiál získaný při hloubení rybníka. 


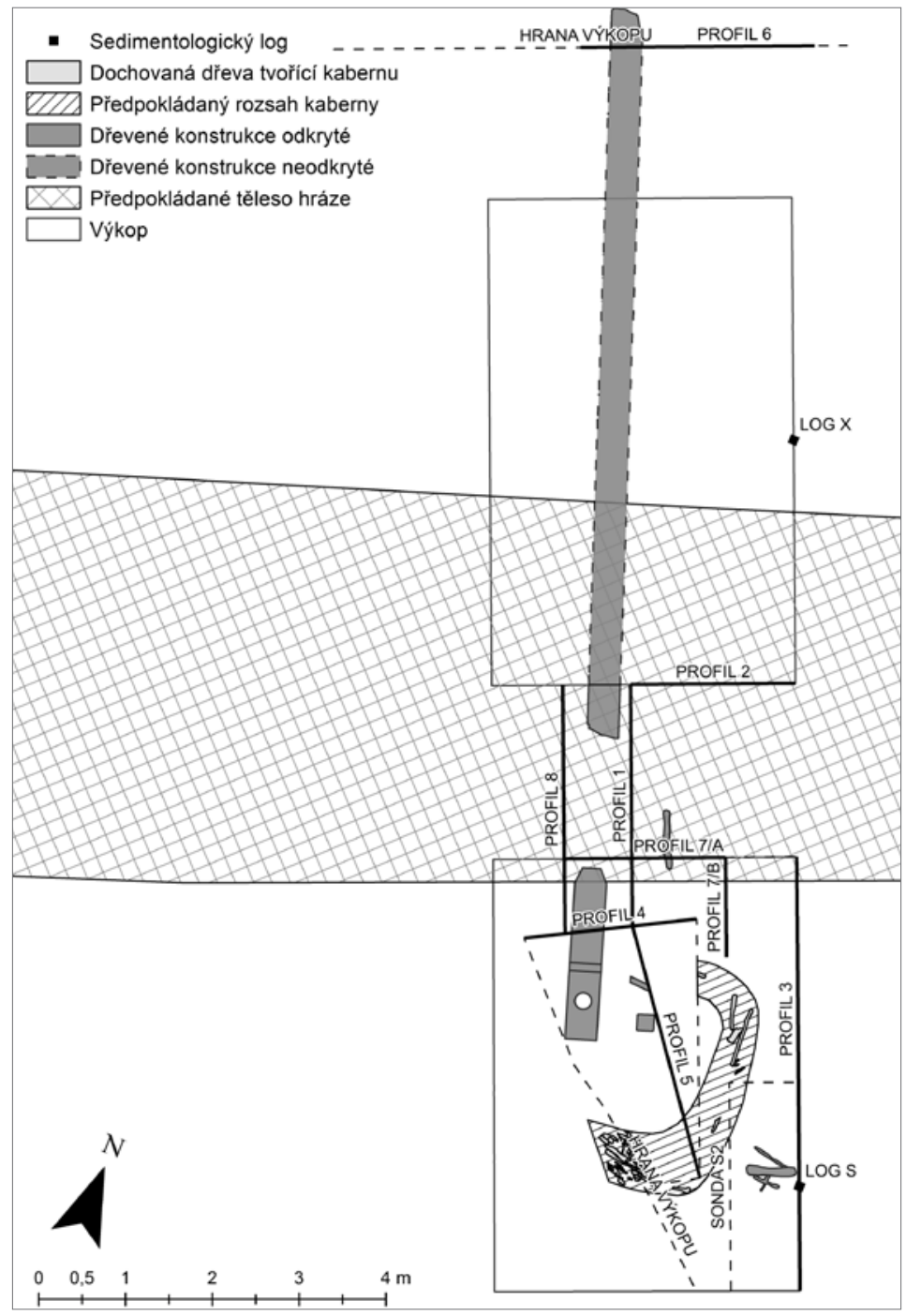

Obr. 7. Plánek pozice dřevených koryt, hráze rybníka a zkoumaných profilů.

Abb. 7. Planskizze der Lage der Holzgerinne, des Teichdammes und der untersuchten Profile.

Rozlohu samotného rybníka vymezují zejména homogenní magnetické hodnoty ve střední a jižní části magnetogramu. Chybějí zde především magnetické dipóly, plocha tudíž očividně nebyla využíána pro žádné jiné antropogenní aktivity. Magnetické hodnoty na ploše rybníka se pohybují v rozmezí $-0,2$ až $0,2 \mathrm{nT}$, zatímco plocha severně a východně vykazuje hodnoty kolem 0,2 až 0,5 nT. Nízké hodnoty z prostoru někdejší vodní plochy poukazují na přítomnost sekundárně naplaveného materiálu, který se zde postupně usazoval po ukončení jejího aktivního využívání pro účely rybníkářství.

Profil hráze rybníka byl identifikován prostřednictvím georadaru, přičemž radarový záznam koresponduje s anomálií zjištěnou při průzkumu magnetometrem. Na získaném radarogramu je 
možno zároveň vysledovat i rozdílný charakter materiálového složení podpovrchových vrstev na lokalitě (obr. 6). Prostor mimo rybník (před hrází) je charakterizován kompaktními vrstvami vzniklými dusáním sedimentu, zatímco prostor za hrází vykazuje četné anomální nehomogenity související s různou zrnitostí sedimentárních vrstev. Zjištění obdržená geofyzikálními metodami tak byla ve shodě s dokumentovanými situacemi při záchranném archeologickém výzkumu.

\subsection{Dokumentace sedimentu v prostoru výplně rybníka a tělesa hráze}

Situace byla sledována ve dvojici výkopů (,jižní výkop“ a „severní výkop“). U severně položeného výkopu byly dokumentovány profily 2 a 6, u výkopu jižního pak profil 3 (prohloubeno sondou), profil 4 a profil 5 (obr. 7). V rámci západního výkopu byly zachyceny také pomocné profily 7/A a 7/B, mezi oběma výkopy byla také dodatečně otevřena další sonda, která umožnila dokumentaci profilu 1 a profilu 8 (obr. 7).

Na dně obou hlavních výkopů byly objeveny dřevěné konstrukce. Jednalo se o dvě koryta vytesaná ze dřeva, shora překrytá dřevěnými víky. Jižní výkop obnažil (z hlediska směru vodního toku) horní prvek této dřevěné konstrukce, označený jako koryto č. 1, a situaci kolem něj. V severním výkopu bylo odkryto koryto č. 2, jehož počátek byl zachycen ve spojovací sondě. Mezi oběma koryty, shodně situovanými v jedné linii rovnoběžně se spádnicí svahu, byla naměřena mezera o průměrné šířce $170 \mathrm{~cm}$. K obnažení koryta č. 1 došlo v celé jeho délce. Koryto č. 2 bylo obnaženo pouze v krajních partiích. V blízkosti koryta č. 1 byl nalezen dřevěný artefakt kruhového průřezu, jenž se v dolní části kuželovitě zužuje. Jeho horní část se nedochovala.

\section{Profil 1}

Vnitřní část hráze a okraj sedimentů uložených v nádrži je možné pozorovat na profilu 1 (obr. 8:A). Tmavě hnědý až šedý prach neuspořádaných násypů (vrstva 5) tvoří těleso hráze. Koruna hráze sestává z vrstvy písčito-jílovitého prachu s drobnými úlomky kamenů (vrstva 12), která je ještě překryta šedým jílovitým prachem s větším kameny (vrstva 11). Vše je převrstveno koluviem (vrstvy 1 a 2 ).

\section{Profil 2}

Profil (obr. 8:B) pravděpodobně zachycuje sypané těleso hráze (vrstvy 3, 4 a 5), které bylo zřejmě narušeno a později vyplněno materiálem odpovídajícím koluviu (vrstva 2).

\section{Profil 3}

Profil 3 (obr. 8:C) probíhá vnitřní částí zaniklé nádrže. Podloží (vrstva 10) tvořené zvětralinou se nachází v hloubce $410 \mathrm{~cm}$. Na něj nasedají fluviální nebo koluviálně-fluviální holocenní sedimenty (vrstva 9). Vrstvy 13 a 8 odpovídají sedimentům uloženým v sedimentačním prostoru nádrže. Vrstvy 5 a 6 odpovídají tělesu hráze. Vrstvy 3,4 a 7 vznikly pravděpodobně po zániku rybníka. Svrchní část profilu je tvořena koluviem s vyvinutým svrchním půdním horizontem (vrstvy 1 a 2).

\section{Profil 4}

Situace v prostoru kolem dřevěného prvku 1 kolmo na jeho osu je viditelná na profilu 5 (obr. 8:D). Dřevěný prvek byl usazen na fluviální nebo koluviálně-fluviální holocenní sedimenty (vrstva 9), které mohly být původně částečně odtěženy, aby bylo dosaženo větší hloubky. Částečně je usazen i v tělese hráze (vrstva 5), kde se ukládaly sedimenty nádrže (vrstva 8).

\section{Profil 5}

Ukazuje neúplný úsek vnitřní části nádrže (obr. 8:E) s vrstvou bohatou na organický materiál, především zbytky dřeva (vrstva 8). Vrstva 5 odpovídá materiálu tělesa hráze, který mohl být rozplaven a uložen ve formě vykliňující vrstvy. 


\begin{tabular}{|c|l|}
\hline Číslo vrstvy & Popis \\
\hline 1 & $\begin{array}{l}\text { hnědý písčito-jílovitý prach se subangulárně hranolovitou strukturou (svrchních ca } 30 \text { cm odpovídá } \\
\text { půdnímu A horizontu) }\end{array}$ \\
\hline 2 & šedý písčito-jílovitý prach se subangulárně hranolovitou stavbou, redukční prostředí \\
\hline 3 & šedooranžová jílovito-prachová hlína s vysráženými Fe oxidy \\
\hline 4 & tmavě hnědý jílovitý prach \\
\hline 5 & tmavě hnědý až šedý (směrem k podloží) jílovitý prach, tvořený neuspořádanými osypy \\
\hline 6 & šedooranžový jílovitý prach s vysráženými Fe oxidy \\
\hline 7 & žlutošedý písčitý prach \\
\hline 8 & zelenošedý jílovitý prach, nad bází přechází do prachového písku \\
\hline 9 & zelenošedý písčito-jlovitý prach, nad bází přechází do prachového písku \\
\hline 10 & úlomky hornin, zvětralé podloží \\
\hline 11 & šedý jílovitý prach s úlomky hornin (5 až 20 cm) \\
\hline 12 & písčito-jílovitý prach, šmouhovaně oranžovo-šedý, s drobnými úlomky hornin (do 5 cm) \\
\hline 13 & tmavě hnědá vrstva bohatá na organické příměsi a rostlinné zbytky \\
\hline
\end{tabular}

Tab. 1. Seznam a popis vrstev.

Tab. 1. Verzeichnis und Beschreibung der Schichten.

\section{Profil 6}

Pohled na konec druhého dřevěného prvku, který je usazen v původním sedimentu (vrstva 9 , obr. 8:F). Zbytek výplně, kterou byl dřevěný prvek překryt, je pravděpodobně vrstva 6 .

\section{Profily $7 A$ a $7 B$}

V tomto profilu je sledovatelný dřevěný prvek, označený jako koryto č. 1, který je usazen v tělesu hráze (vrstvy 5 a 3, obr. 8:G). Zbytek sedimentů usazených v nádrži představuje vrstva 8 . Vše je překryto koluvii (vrstvy 1 a 2 ).

\section{Profil 8}

Tento profil zachycuje oba dřevěné prvky (koryto č. 1 a koryto č. 2) a kontext, který je odděluje (obr. 8:H). Prostor mezi nimi je vyplněn stejným nebo podobným materiálem, jenž tvoří i těleso hráze (vrstva 5). Ta je částečně překryta rozrušenou vrstvou 9 , která mohla být deformována pohybem svahu. Prostor nad vrstvou 9 je vyplněn vrstvou 6 . V nenarušené části nad dřevěným prvkem je uložen další materiál odpovídající vrstvě 5 . Vše je překryto svahovinami.

\section{Vzorkovaci bod $1(\log X)$}

Hodnoty popisující zrnitost (poměr jílu, hrubého prachu, velmi hrubého prachu a písku), magnetickou susceptibilitu a množství organické hmoty v profilu se vzorkovacím bodem 1 (v prostoru hráze rybníka) jsou uvedeny v diagramu na obr. 9 (nahoře). V hloubce $410-370 \mathrm{~cm}$ je dokumentován písčitý sediment s narůstajícím podílem prachové složky a s vyšším obsahem organického materiálu v hloubce $390 \mathrm{~cm}$. Vzhledem k př́tomnosti písčitých vrstev se jedná pravděpodobně o aluviální sedimenty drobného toku. V hloubce $370-300 \mathrm{~cm}$ byl zachycen písčitý prach s vysokou magnetickou susceptibilitou na povrchu. Jednalo se pravděpodobně o původní aluviální materiál, který se vyznačoval nižším zastoupením písčité frakce a vyšším zastoupením organické hmoty. Přibližně od 300 do $110 \mathrm{~cm}$ je materiál zrnitostně velmi jemný (jílovitý prach) s nízkou magnetickou susceptibilitou (kromě báze) a nízkým zastoupením organické hmoty. Tento sediment byl pravděpodobně použit ke stavbě hráze. Od $110 \mathrm{~cm}$ směrem k povrchu je sediment tvořen písčitým prachem se zvýšenými hodnotami magnetické susceptibility a vyšším 


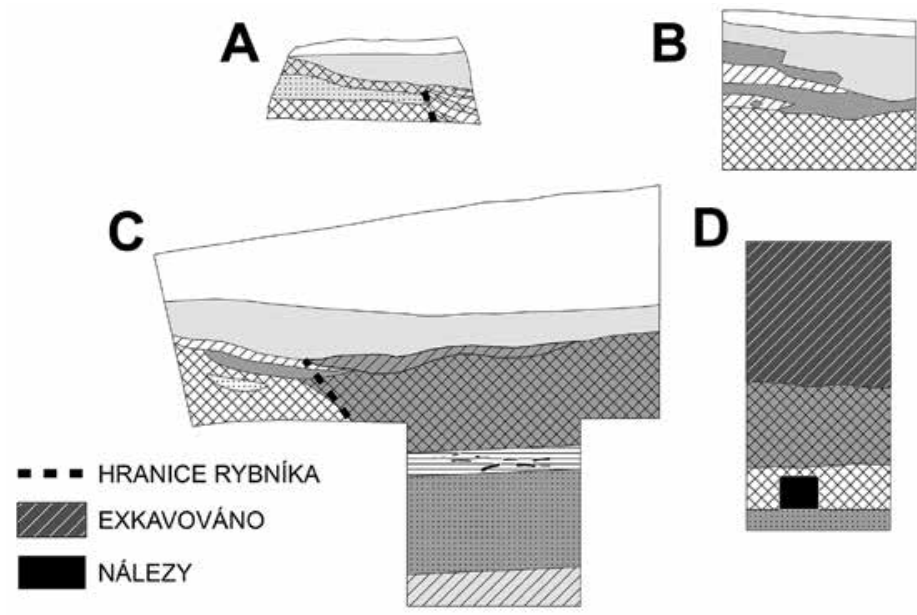

\section{ULOŽENINY}
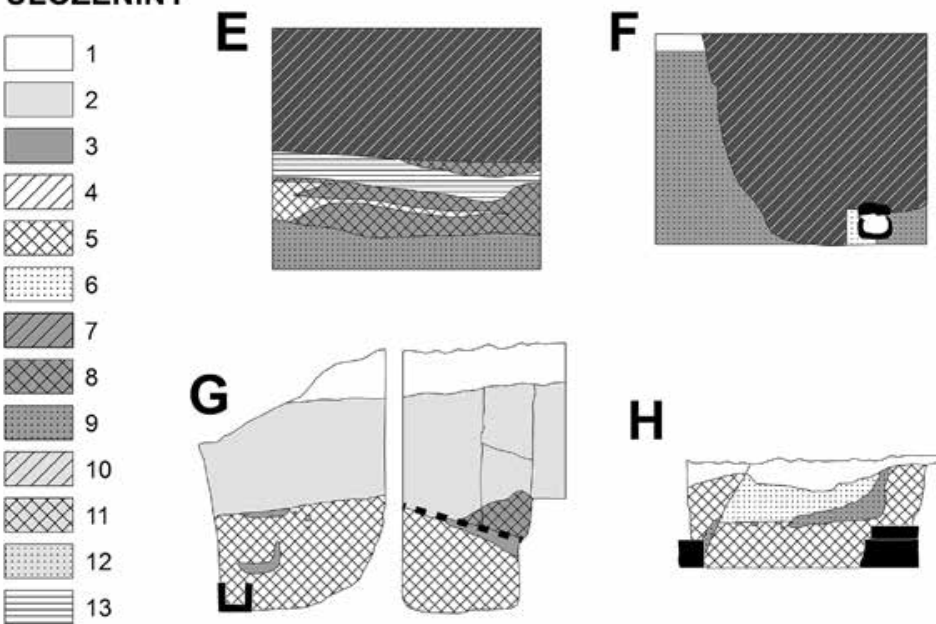

H
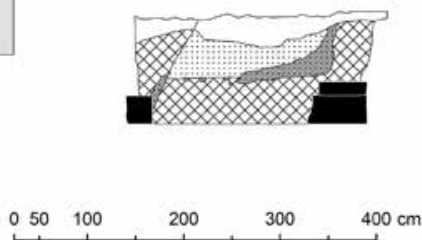

Obr. 8. Zkoumané profily. A - profil 2, B - profil 3, C3 -profil 4, D - profil 5, E - profil 6, F - profil 7, G - profily I/A a II/A, H - profil II.

Abb. 8. Untersuchte Profile. A - Profil 2, B - Profil 3, C3 -Profil 4, D - Profil 5, E - Profil 6, F - Profil 7, G - Profile I/A und II/A, H - Profil II.

podílem organického materiálu při povrchu. Jedná se o splachy antropogenního původu, na nichž je vyvinutá půda.

\section{Vzorkovaci bod $2(\log S)$}

Hodnoty vzorků ze vzorkovacího bodu 2 (v prostoru výplně rybníka) jsou uvedeny v diagramu na obr. 9 (dole). V hloubce $410-370 \mathrm{~cm}$ bylo zachyceno aluvium tvořené písčitým prachem s úlomky hornin, nízkými hodnotami magnetické susceptibility a vrstvami s vyšším podílem organické hmoty. V hloubce $370-260 \mathrm{~cm}$ se vyskytovaly pravděpodobně mladší aluviální sedimenty tvořené písčitým prachem, $\mathrm{v}$ hloubce $260-250 \mathrm{~cm}$ pak prachové sedimenty s úlomky 

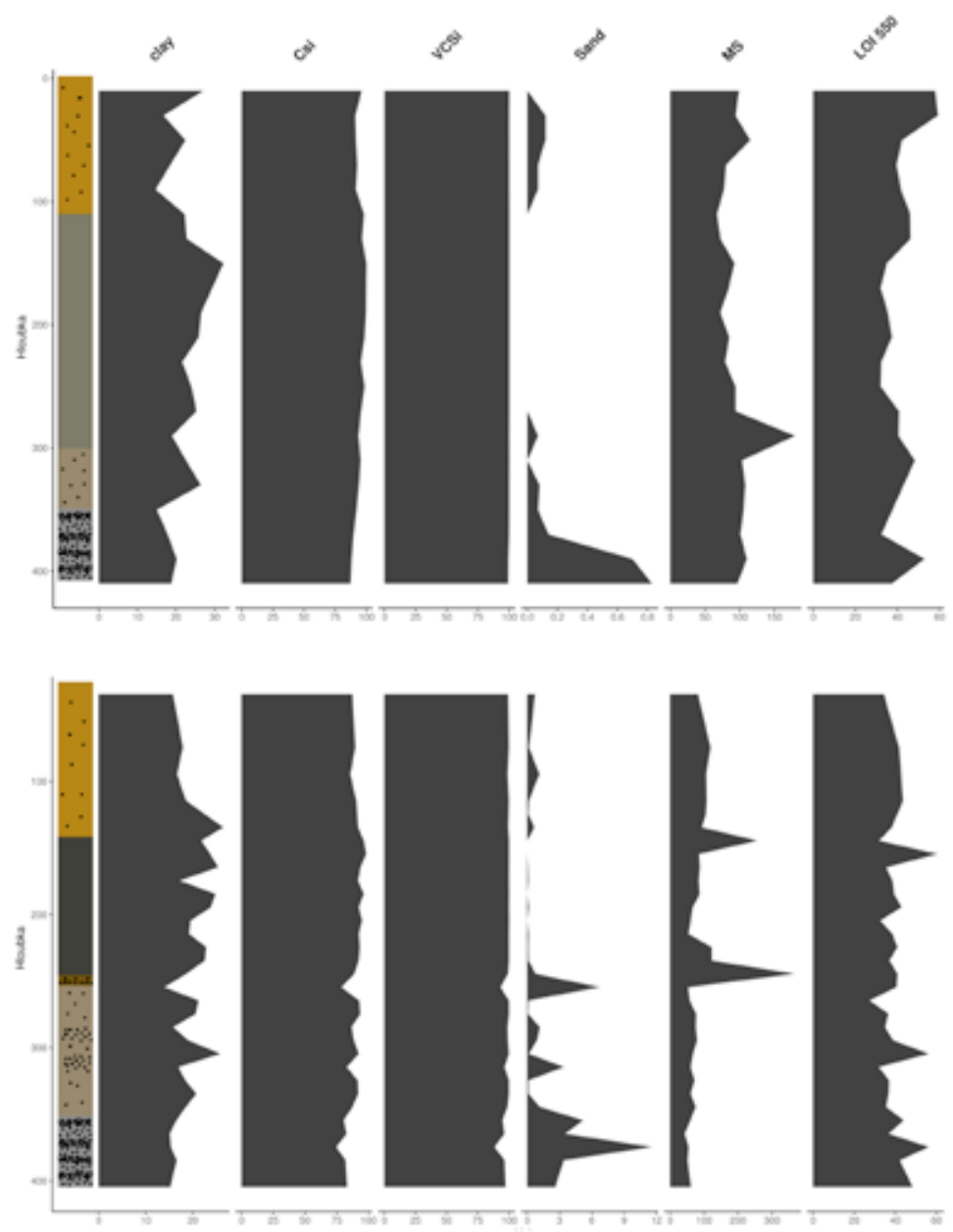

Obr. 9. Zrnitost, magnetická susceptibilita a zastoupení organické hmoty vzorků odebraných z dokumentačního bodu 1 (nahoře) a z dokumentačního bodu 2 (dole).

Abb. 9. Körnung, magnetische Suszeptibilität und Vorkommen organischer Stoffe der an Dokumentationspunkt 1 (oben) und Dokumentationspunkt 2 (unten) entnommenen Proben.

dřeva. Vysoká hodnota magnetické susceptibility může svědčit o obohacení magnetickým materiálem souvisejícím s dosud neupřesněnou výrobní činností. V hloubce $250 \mathrm{~cm}$ je možno předpokládat někdejší rybniční dno. V hloubce $250-150 \mathrm{~cm}$ byly doloženy jílovito-prachové sedimenty, které vznikly depozicí v prostředí vodní nádrže. Jejich svrchní partie akumulované před úplným zanesením nádrže vykazovaly vyšší hodnoty magnetické susceptibility a organické hmoty. Od hloubky $150 \mathrm{~cm}$ směrem k povrchu byly dokumentovány splachy tvořené písčitým prachem.

\subsection{Dřevěné prvky a jejich dendrochronologické datování}

Základní tvar koryta č. 1 (jižněji) byl hranol, do nějž byl vyhlouben žlab se svislými stěnami a vodorovným dnem. Nad částí žlabu byla upevněna dubová krycí deska. V blízkosti koryta č. 1 byl nalezen dřevěný artefakt kruhového průřezu, jenž se v dolní části kuželovitě zužuje („dř̌evěný hranol“). Jeho horní část se nedochovala. Část kruhového průřrezu přesně pasuje do otvoru v korytě č. 1 . Koryto č. 2 bylo situováno níže po svahu (severněji) a bylo zhotoveno 

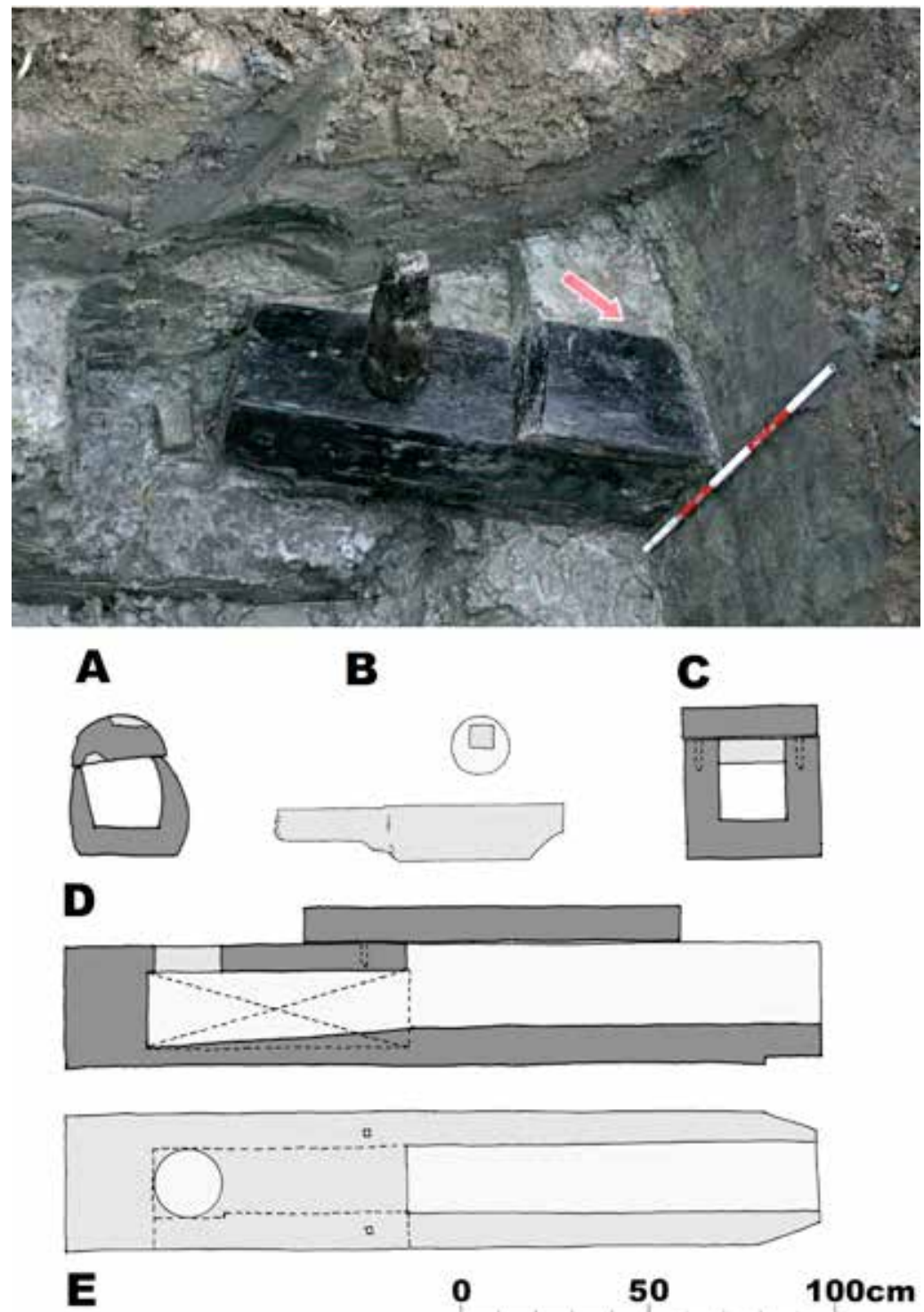

Obr. 10. Fotografie dřevěných prvků vypouštěcího zař́izení (dole). Jednotlivé dřevěné prvky (nahoře). A - kolmý průřez dřevěným prvkem 2, B - „kuláč“, C-kolmý průřez dřevěným prvkem $1, \mathrm{D}$ - podélný průřez dřevěným prvkem $1, \mathrm{E}$ - vrchní kolmý pohled na dřevěný prvek č. 1 .

Abb. 10. Fotografie der Holzelemente einer Ablassvorrichtung (unten). Einzelne Holzelemente (oben). A - Querschnitt von Holzelement 2, B - „Rundholz“, C - Querschnitt von Holzelement 1, D - Längsschnitt von Holzelement 1, E - obere Queransicht von Holzelement Nr. 1.

$\mathrm{z}$ jedlového kmene. $\mathrm{V}$ prostoru ca 1-2 m od koryta č. 1 byla zachycena část dřevěného brlení (kaberny) původně tvořícího oválný čtyřúhelník (obr. 7). Ze zásypu byla vyzvednuta dubová fošna, která se podle stratigrafické pozice v zásypu (obr. 8 , profil $\mathrm{H}$, vrstva 5 ) dostala do prostoru později. Dřevěné prvky jsou vyobrazeny na obr. 10 . 
$\mathrm{V}$ rámci průzkumu byly $\mathrm{z}$ dřevěných prvků nalezených ve výkopu odebrány vzorky pro dendrochronologické datování. Přehled těchto vzorků s počtem letokruhů a výslednými daty je uveden v tabulce 2. Vzorek č. 1 pocházel ze subtilního prvku nalezeného v blízkosti kruhového otvoru koryta č. 1 („dřevěný hranol“), datum se z něj však nepodařilo získat. Tento prvek byl vyhotoven z dubu. Další vzorek byl odebrán z fošny nalezené ve výkopu bez př́mé souvislosti s popisovanými dřevěnými prvky (v horních vrstvách). Fošna byla zhotovena taktéž z dubu a jako jediná $z$ datovaných prvků poskytla mladší datum (1536/1537). Dále byly odebrány vzorky z obou čel koryta č. 1 i z jeho krycích desek. Stejně tak bylo ovzorkováno koryto č. 2 včetně krycí desky. V těchto př́ípadech se podařilo prokazatelně stanovit dobu pokácení stromů (jedlí) na $1488 / 1489$. Lze předpokládat, že prvky byly vyrobeny nedlouho po pokácení stromů, tedy počátkem 90 . let 15 . století.

\subsection{Keramické artefakty}

Areál zaniklého rybníka a jeho blízkého okolí poskytl nevelký soubor fragmentů keramiky. Kolekce byla získána převážně povrchovým sběrem při výkopech meliorační rýhy z oblasti mezi hrází a koncem údolí (obr. 11:A, B, C), část pak při dokumentaci archeologických struktur z tělesa hráze (obr. 11:D, E), z někdejšího rybničního dna (obr. 11:F, vrstva 5 z profilu 5 u pylonu vedle kaberny) a z míst nad rybníkem proti proudu vodoteče (obr. 11:G, H). Vymezení koncentrací keramiky z prostoru „mezi hrází a koncem údoli““ a z prostoru míst „nad rybníkem proti proudu vodoteče“ je zaznamenáno na obrázku 3 (obr. 3:6, 7). Získanou kolekci zlomků můžeme datovat pouze rámcově. Narážíme zde zejména na nedostatek exaktně datovaných vrcholně středových souborů keramiky z prostoru nejvýchodnější Moravy (srov. napr. Kohoutek 2003). Střechovitě přehnutý (vně vyhnutý) okraj (obr. 11:A) tvarově odpovídá keramice 14. století, přičemž analogie bychom mohli nalézt v kolekcích jak z městského prostředí (viz Bartík a kol. 2016, obr. 9:6), tak i z některých východomoravských hradů (Kohoutek 2003, obr. 18 a dále). Výrazný je také zlomek podhrdlí zdobený radélkem (obr. 11:F). Vzhledem k tomu, že se jedná o hrubší materiál bez obsahu grafitu, je jeho datování do druhé poloviny 13. století jen podle výzdoby problematické. Lze tedy spíše předpokládat, že se jedná o mladší keramiku 14., či spíše až 15. století. Datování naznačuje i stratigrafická poloha fragmentu ve vrstvě $5 \mathrm{z}$ doby fungování rybníka.

Získaný soubor obsahuje také starší keramiku (obr. 11:D, E), u níž nelze vyloučit ani datování do pravěku. Přítomnost pravěkých keramických fragmentů naznačuje jednak dřivější osídlení lokality (srovnej např. se Skutil 1937-1938; případně Dohnal 1977, 61-65), ale také narušování starších archeologických kontextů erozí nebo stavebními pracemi.

\subsection{Palynologie}

Palynologicky analyzován byl profil se vzorkovacím bodem 2 (obr. 12). Nivní sedimenty pod vlastní výplní rybníka neobsahovaly determinovatelná pylová zrna, podobně i vrstvy mělčí než $70 \mathrm{~cm}$ byly pylově sterilní. Pylové spektrum výplně (70 až $269 \mathrm{~cm})$ vykazovalo velmi

\begin{tabular}{|l|c|c|c|c|}
\hline \multicolumn{1}{|c|}{ popis prvku } & číslo vzorku & dřevina & počet letokruhů / letokruhů běle & datum skácení \\
\hline dřevěný hranol & S9001 & dub & $39 / 7$ & - \\
\hline fošna & S9002 & dub & $170 / 15$ & $1536 / 1537$ \\
\hline koryto č. 1 & S9006 & jedle & 34 & $1488 / 1489$ \\
\hline poklop koryta č. 1 & S9007 & jedle & 59 & $1488 / 1489$ \\
\hline poklop koryta č. 1 & S9005 & jedle & 59 & $1488 / 1489$ \\
\hline koryto č. 2 & S9004 & jedle & 25 & $1488 / 1489$ \\
\hline poklop koryta č. 2 & S9003 & jedle & $33+1$ & $1488 / 1489$ \\
\hline
\end{tabular}

Tab. 2. Druhy dřevin a dendrochronologická data dřevěných prvků.

Tab. 2. Arten der Hölzer und dendrochronologische Daten der Holzelemente. 


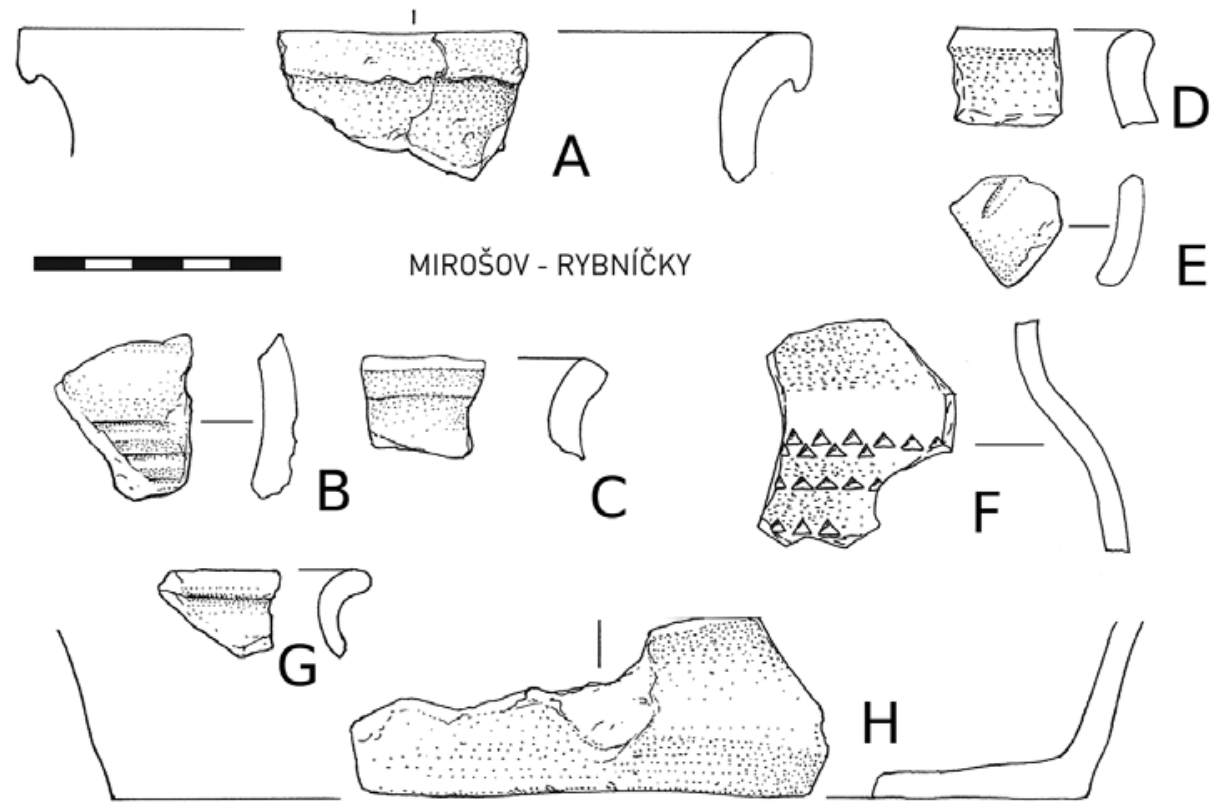

Obr. 11. Keramika objevená při archeologickém výzkumu pozůstatků rybníka. A, B, C - z prostoru mezi hrází a začátkem údolí; $\mathrm{D}, \mathrm{E}$ - z tělesa hráze; $\mathrm{F}$ - z někdejšího rybničního dna; $\mathbf{G}, \mathbf{H}-\mathrm{z}$ míst nad rybníkem proti proudu vodoteče.

Abb. 11. Bei der archäologischen Untersuchung der Teichüberreste entdeckte Keramik. A, B, C - im Bereich zwischen Damm und Anfang des Tals; D, E - im Dammkörper; F - im einstigen Teichboden; G, H - im Bereich oberhalb eines Teiches stromaufwärts.

malou variabilitu a mírně odlišné byly jen tři spodní vzorky. Poměr pylu dřevin a bylin (AP/ NAP ratio) se pohyboval mezi 50 až $20 \%$. V pylovém spektru dřevin je nejvýrazněji zastoupena líska (Corylus avellana), dále je zde výrazný podíl borovice (Pinus), smrku (Picea abies), břízy (Betula), méně častý je dub (Quercus), jedle (Abies), buk (Fagus), lípa (Tilia) a vlhkomilná olše (Alnus). Ve spektru bylin převažoval pyl trav (Gramineae) s podílem okolo 30\%. Druhým nejčastějším taxonem byl pyl obilovin (Ceralia) a čeledi hvězdnicovitých (Asteraceae). Zachyceny byly i typické plevele obilných polí, a to chrpa modrák (Centaurea cyanus) a koukol (Agrostema githago). Z pěstovaných rostlin byla doložena pohanka (Fagopyrum esculentum) a ojediněle pyl konopí (Cannabis/Humulus-typ) a lnu (Linum). Časté byly ruderální druhy a pastevní indikátory jako jitrocel kopinatý (Plantago lanceolata), jitrocel větší (P. maior), štovík menší (Rumex acetosella-typ), pelyněk (Artemisia), čeled' merlíkovitých (Chenopodiaceae) nebo kopřiva (Urtica). Lokální mokřadní vegetaci indikuje pyl ostřic (Cyperaceae). Prakticky nebyly zachyceny zelené řasy r. Pediastrum, což bylo dáno průtočností vodní nádrže.

Obsah vzorku odebraného z úrovně povrchu byl pozoruhodně podobný fosilnímu pylovému spektru, jedinou odlišností byl vyšší podíl pylu trav (Gramineae), buku (Fagus) a habru (Carpinus betulus). Naopak ruderální taxony byly méně frekventované. Podíl lesa a jeho druhová skladba byla v 15. a 16. století relativně podobná jako dnes, naopak okolí rybníka bylo více ruderalizované.

\subsection{Rostlinné makrozbytky}

Zastoupení rostlinných makrozbytků v profilech ze vzorkovacích bodů 1 a 2 i z koryta č. 1 je uvedeno v tabulce (tab. 3). Srovnání relativního zastoupení ekologických skupin ilustruje obr. 13. 


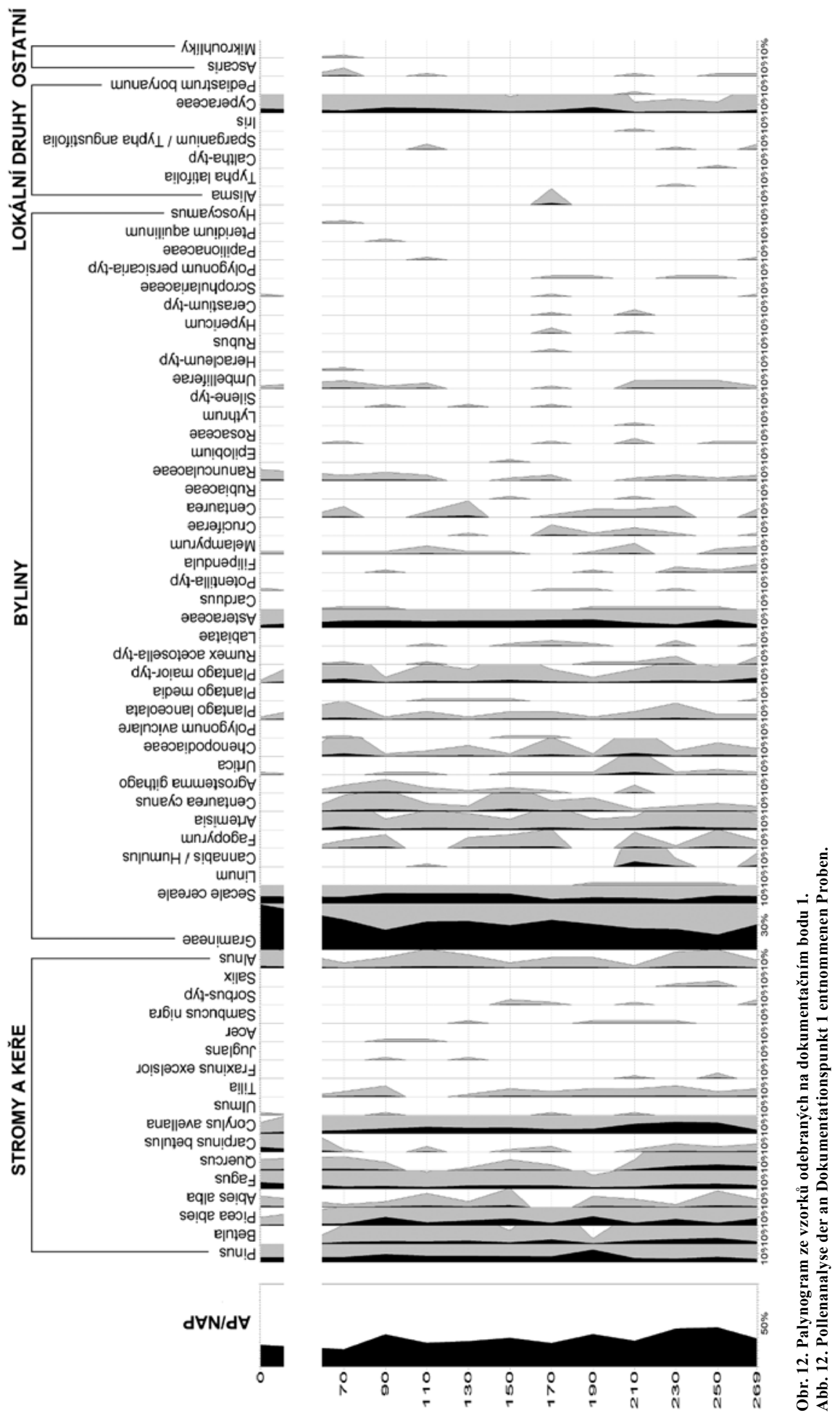




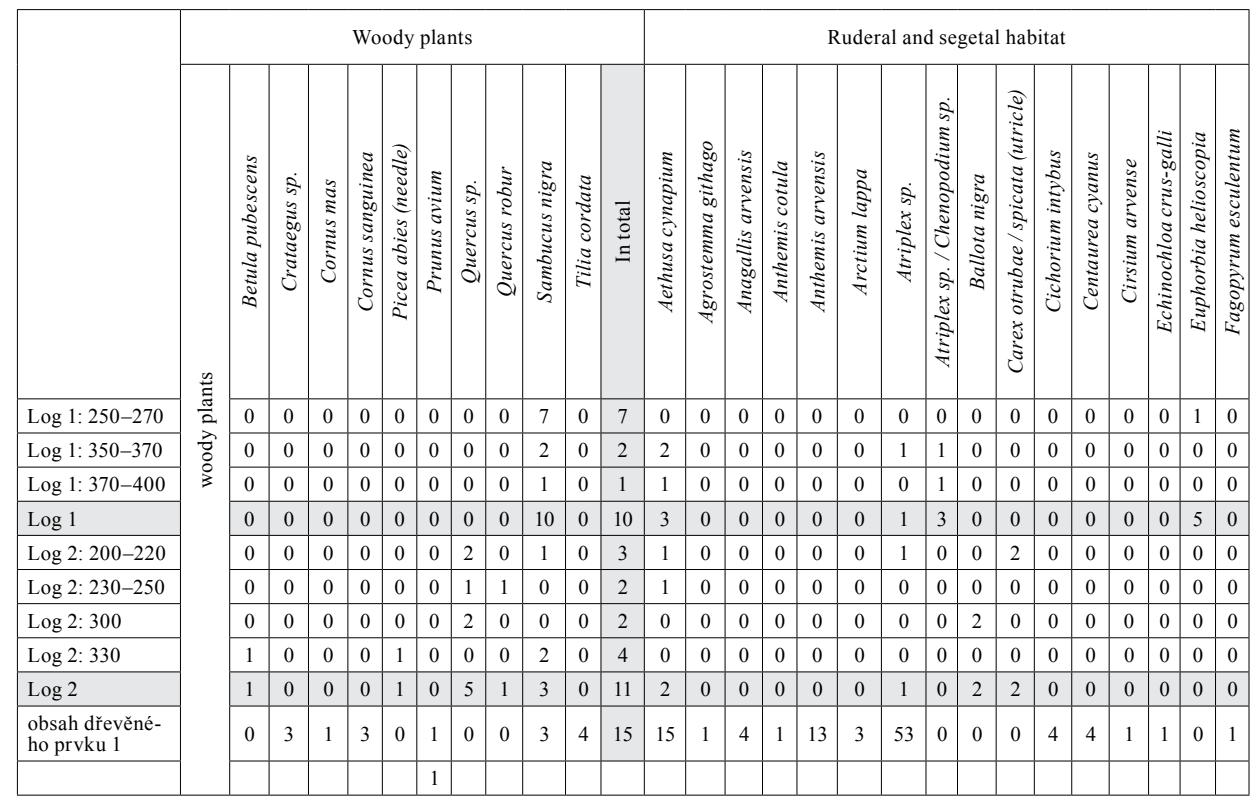

$\log 1: 250-270$

$\log 1: 350-370$

Log 1: $370-400$

$\log 1$

$\log 2: 200-220$

$\log 2: 230-250$

$\log 2: 300$

$\log 2: 330$

$\log 2$

obsah dřevěné-

ho prvku 1

\begin{tabular}{|c|c|c|c|c|c|c|c|c|c|c|c|c|c|c|c|c|c|c|c|c|c|c|c|c|c|}
\hline \multirow{12}{*}{ 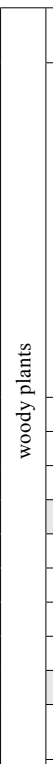 } & \multicolumn{8}{|c|}{$\begin{array}{l}\text { Hydrophilous species of forests } \\
\text { and shrubberies }\end{array}$} & \multicolumn{17}{|c|}{ Species of stillwaters and slowly flowing waters, exposed pond bottoms } \\
\hline & 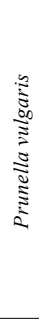 & 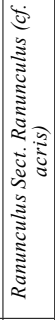 & 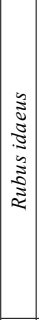 & 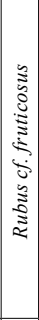 & 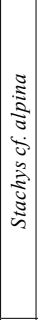 & 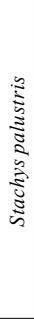 & 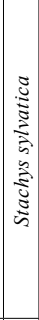 & $\begin{array}{l}\bar{\Xi} \\
\stackrel{\Xi}{\Xi} \\
\Xi\end{array}$ & 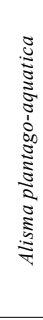 & 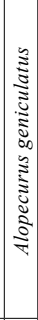 & 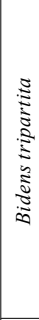 & 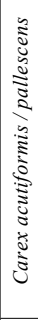 & 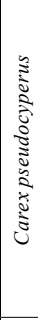 & 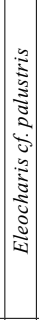 & 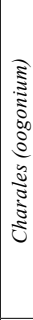 & 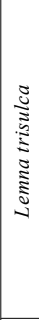 & 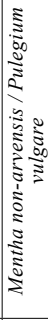 & 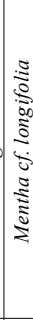 & 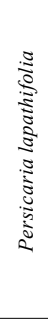 & 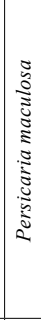 & 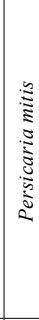 & 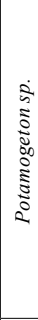 & 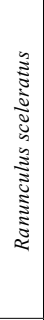 & 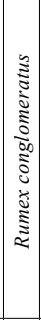 & 5 \\
\hline & 0 & 2 & 3 & 0 & 0 & 0 & 2 & 8 & 0 & 0 & 0 & 0 & 0 & 0 & 0 & 0 & 0 & 0 & 0 & 0 & 0 & 0 & 0 & 0 & 0 \\
\hline & 0 & 2 & 1 & 0 & 0 & 0 & 1 & 10 & 0 & 0 & 1 & 0 & 2 & 1 & 4 & 1 & 6 & 2 & 1 & 1 & 0 & 0 & 3 & 0 & 0 \\
\hline & 0 & 2 & 1 & 0 & 0 & 0 & 2 & 6 & 2 & 0 & 0 & 0 & 1 & 0 & 0 & 5 & 3 & 0 & 0 & 0 & 0 & 1 & 2 & 0 & 0 \\
\hline & 1 & \begin{tabular}{|l|l|} 
\\
\end{tabular} & 6 & 0 & 0 & 0 & 5 & 166 & 2 & 0 & 1 & 14 & 14 & 1 & 4 & 6 & 9 & 2 & 1 & 1 & 0 & 2 & 5 & 0 & 0 \\
\hline & 0 & 19 & \begin{tabular}{|l|} 
\\
\end{tabular} & 0 & 1 & 0 & 0 & 22 & 0 & 0 & 0 & 1 & 0 & 1 & 0 & 0 & 0 & 0 & 39 & 0 & 2 & 6 & 2 & 0 & 0 \\
\hline & 0 & 7 & 0 & 0 & 0 & 0 & 0 & 7 & 2 & 0 & 0 & 0 & 0 & 0 & 0 & 0 & 0 & 0 & 0 & 0 & 1 & 1 & 2 & 0 & 2 \\
\hline & 0 & 0 & \begin{tabular}{|l|}
0 \\
\end{tabular} & 0 & \begin{tabular}{|l|} 
\\
\end{tabular} & 0 & 0 & 0 & 0 & 0 & 0 & 0 & 0 & 0 & 0 & 0 & 0 & 0 & 0 & 0 & 0 & 0 & 0 & 0 & 0 \\
\hline & 0 & 0 & \begin{tabular}{|l|}
0 \\
\end{tabular} & 0 & \begin{tabular}{l|} 
\\
\end{tabular} & 0 & 0 & 1 & 0 & 0 & 0 & 0 & 0 & 0 & 0 & 0 & 0 & 0 & 0 & 0 & 0 & 0 & 0 & 0 & 0 \\
\hline & 0 & 26 & 0 & 0 & 1 & 0 & 0 & 30 & 2 & 0 & 0 & 1 & 0 & 1 & 0 & 0 & 0 & 0 & 9 & 0 & 3 & 7 & 4 & 0 & 2 \\
\hline & 1 & 22 & 0 & 1 & 0 & 2 & 9 & 117 & 107 & 3 & 33 & 1 & 0 & 0 & 0 & 15 & 5 & 0 & 196 & 0 & 14 & 18 & 47 & 2 & 0 \\
\hline & & & & & & & & & & & & & & & & & & & & & & & & & \\
\hline
\end{tabular}

Tab. 3. Druhy rostlin a jejich počty zjištěné analýzou rostlinných makrozbytků ze vzorků sedimentu.

Tab. 3. Pflanzenarten und ihre anhand einer Analyse der aus den Sedimentproben gewonnenen Pflanzenmakroreste. 


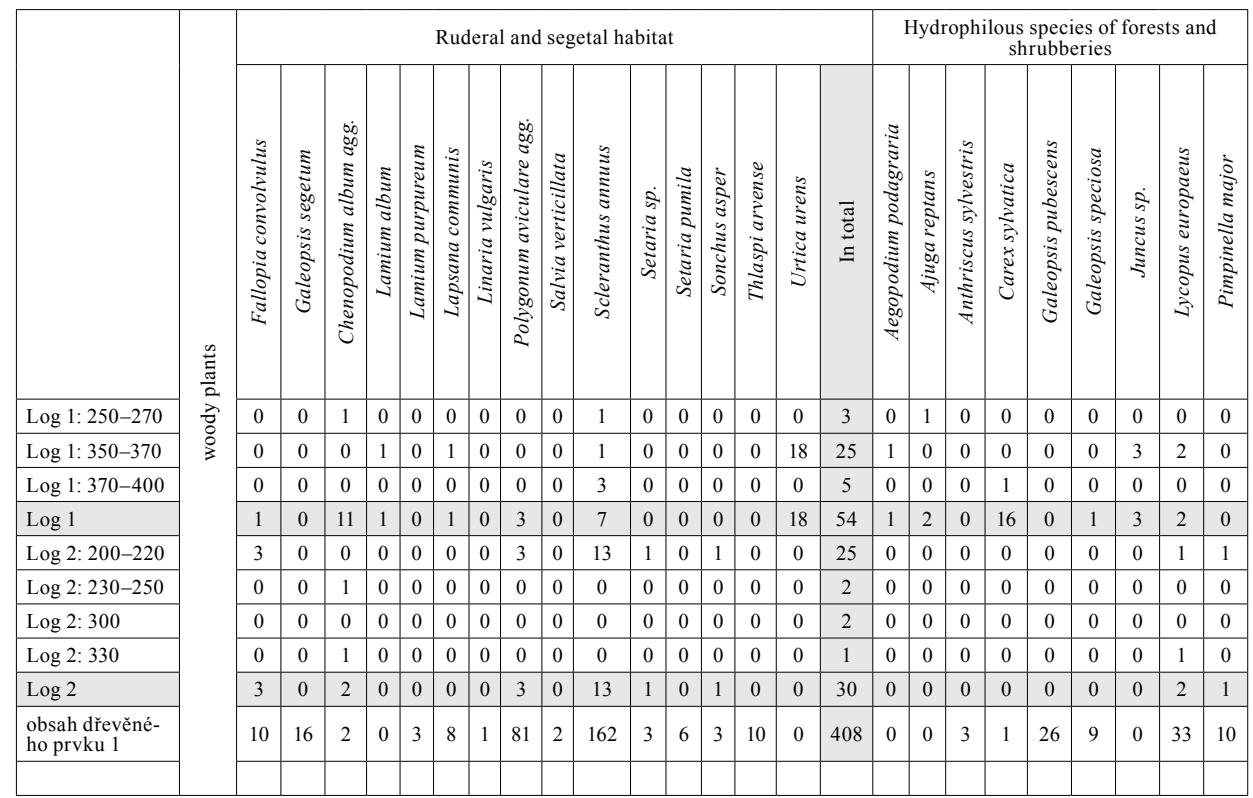

$\log 1: 250-270$

Log 1: 350-370

Log 1: 370-400

$\log 1$

Log 2: 200-220

$\log 2: 230-250$

$\log 2: 300$

$\log 2: 330$

$\log 2$

obsah dřevěné-

ho prvku 1

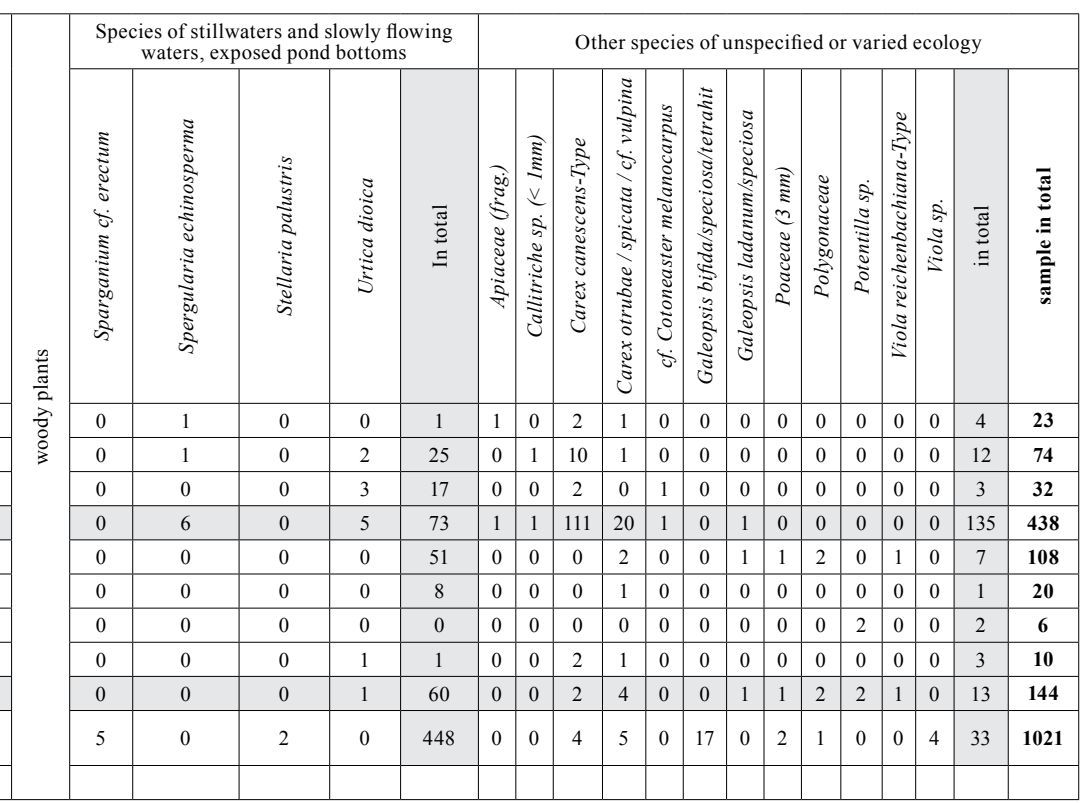

Tab. 3. Druhy rostlin a jejich počty zjištěné analýzou rostlinných makrozbytků ze vzorků sedimentu.

Tab. 3. Pflanzenarten und ihre anhand einer Analyse der aus den Sedimentproben gewonnenen Pflanzenmakroreste. 


\section{Rostlinné makrozbytky z profilu při vzorkovacím bodu 1}

Profil se vzorkovacím bodem 1 poskytl celkem pět vzorků, jež ukázaly na významné zastoupení druhů vlhkých lesů a křovin, a to i přes fakt, že jedinou zaznamenanou dřevinou byl bez černý (Sambucus nigra). Velkou měrou totiž byly zastoupeny pryskyřníky sekce Ranunculus, pravděpodobně pryskyřník prudký (Ranunculus acris). Druhým nejčastějším druhem byla ostřice lesní (Carex sylvatica) preferující vlhká, polostinná až stinná stanoviště. Významná část těchto druhů patří do ekologické skupiny vázané na litorály a rybniční dna. Další skupinou pak byly druhy segetální jako merlík bílý (Chenopodium album agg.), kopřiva žahavka (Urtica urens), tetlucha kozí pysk (Aethusa cynapium) a zuhelnatělá semena chmerku ročního (Scleranthus annuus). Vodní prostředí indikovala oogonia zelené řasy rodu parožnatka (Chara sp.) a semena okřehku trojbrázdého (Lemna trisulca). Oba taxony vyžadují neeutrofizovanou průzračnou vodu.

\section{Rostlinné makrozbytky z profilu při vzorkovacím bodu 2}

Ze vzorkovacího bodu 2 byly zpracovány čtyři vzorky, které také indikují existenci rybníka, ačkoliv obsah makrozbytků je nižší než ve vzorkovacím bodu 1 a výpusti. Celkově mají podobné složení. Zachyceny byly dřeviny, a to žaludy dubu letního (cf. Quercus robur) a dále bez černý (Sambucus nigra), smrk ztepilý (Picea abies) a bříza bělokorá (Betula pubescens) jako druhy původních lesů a sekundární vegetace. Segetální vegetace byla zastoupena chmerkem ročním (Scleranthus annuus), který preferuje narušovaná stanoviště. Rdesno blešník (Persicaria

\begin{tabular}{|c|c|c|c|c|c|c|c|c|c|}
\hline & & & 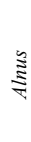 & $\overbrace{0}^{3}$ & $\begin{array}{l}\vdots \\
\vdots \\
5 \\
\vdots \\
\vdots \\
\vdots \\
0 \\
0\end{array}$ & 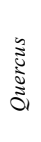 & 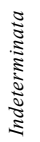 & 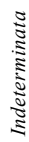 & \\
\hline profil & sonda & $\begin{array}{l}\text { hloubka } \\
\text { (cm) }\end{array}$ & $\frac{\pi}{0}$ & $\underline{\tilde{g}}$ & 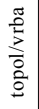 & き & 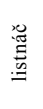 & 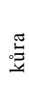 & \\
\hline 4 & 2 & $250-230$ & & 1 & & 20 & 16 & 1 & 38 \\
\hline $\begin{array}{c}\text { koryto } \\
\text { č. } 1\end{array}$ & & & 1 & 6 & 8 & 6 & 6 & & 27 \\
\hline celkem & & & 1 & 7 & 8 & 26 & 22 & 1 & 65 \\
\hline
\end{tabular}

Tab. 4. Výsledky analýzy nezuhelnatělého dřeva, počet analyzovaných fragmentů dřeva (ks).

Tab. 4. Ergebnisse der Analyse unverkohlter Hölzer, Anzahl der analysierten Holzfragmente (Stückzahl). lapathifolia) je druh typický pro břehy vodních ploch, rybniční dna a vlhké ruderály.

\section{Rostlinné makrozbytky z koryta č. 1}

Jeden analyzovaný vzorek odebraný z prostoru výpusti obsahoval ve srovnání se vzorky ze vzorkovacích bodů 1 a 2 relativně větší množství makrozbytků. Prostor výpusti tak mohl fungovat jako past na zachycování plovoucího rostlinného materiálu. Dřeviny jsou reprezentovány opět dubem (Quercus sp.), smrkem ztepilým (Picea abies) a bezem černým (Sambucus nigra). Dalšími identifikovanými druhy byly třešeň ptačí (Prunus avium), lípa srdčitá (Tilia cordata) a bříza bělokorá (Betula pubescens). Zajímavý byl také

\begin{tabular}{|c|c|c|c|c|c|c|c|c|c|}
\hline & & & 离 & نं & 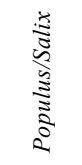 & 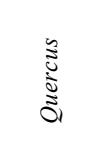 & 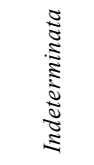 & 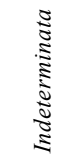 & \\
\hline profil & sonda & $\begin{array}{l}\text { hloubka } \\
(\mathrm{cm})\end{array}$ & 总 & 䓤 & 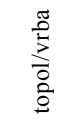 & $\vec{z}$ & 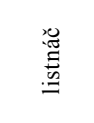 & 䙳 & \\
\hline 4 & 2 & $250-230$ & & 0,7066 & & 17,9163 & 19,2289 & 0,5154 & 38,3672 \\
\hline koryto č. 1 & & & 0,2371 & 3,9576 & 9,6039 & 10,0201 & 11,3512 & & 35,1699 \\
\hline celkem & & & 0,2371 & 4,6642 & 9,6039 & 27,9364 & 30,5801 & 0,5154 & 73,5371 \\
\hline
\end{tabular}

Tab. 5. Výsledky analýzy nezuhelnatělého dřeva, hmotnost analyzovaných fragmentů dřeva (g). Tab. 5. Ergebnisse der Analyse unverkohlter Hölzer, Masse der analysierten Holzfragmente (g). 
výskyt dřínu (Cornus mas), který je dnes rozšířen pouze v nejteplejších oblastech České republiky a jen výjimečně zasahuje do pahorkatin. Doložená lnice květel (Linaria vulgaris) roste oproti tomu na suchých ruderálních stanovištích, a ukazuje tak na variabilitu prostředí okolo rybníka. Segetální druhy zastupuje chmerek roční (Scleranthus annuus).

\section{Determinace fragmentů dreva z koryta č. 1 (tab. 4 a 5)}

Vzorky z koryta č. 1 obsahovaly zlomky dřeva dubu (Quercus), lísky (Corylus), olše (Al$n u s$ ), topolu či vrby (Populus/Salix) a zlomky dřeva a kůry blíže neurčitelné (Indeterminata). V okolí rybníka tedy rostla lužní dřevinná vegetace vrbin a olšin (pravděpodobně vrba a olše), dále pak dub a líska.

\section{Diskuse}

Průzkum širšího zázemí rybníka na katastru obce Mirošov prokázal, že jeho archeologicky zkoumané pozůstatky souvisejí s dalšími identifikovanými středověkými a časně novověkými terénními relikty. $\mathrm{K}$ hrázi vede sít' úvozů, na jednom z nich byla nalezena mince z první poloviny 17. století, která odkazuje na aktivní využívání cesty v době nedlouho po zániku rybníka. $\mathrm{V}$ rámci archeologického výzkumu mirošovského rybníka byly nalezeny i zlomky středověké keramiky a také relativně dobře zachované dřevěné konstrukční prvky, jejichž dendrochronologické zařazení do období po roce 1488 datuje konstrukci rybníka do období hospodaření Podmanických.

Budování rybniční sítě na brumovském panství probíhalo zhruba ve stejném období, kdy vzkvétalo rybníkářství v jižních a východních Čechách, tedy mnohem dř́ive, než je této oblasti rybniční hospodaření přisuzováno historickým bádáním. Existence dalších vodních děl, jež jsou v širším okolí rybníka v Mirošově patrná na výstupech z laserového skenování LiDAR, ilustruje technické řešení rybničních chovů tehdejší doby. Obecně se v polovině 15. století setkáváme s doklady dvourybničního systému - menší z páru rybničních děl bylo určeno k chovu potěru a větší pro dospívající kapry. Na konci 15. století byl tento systém inovován na třírybníkový: nejmenší byly rybníky třecí, středními byly tzv. výtažníky a ve třetím roce byli kapři přemístěni do největších rybníků „na výrost“ (Míka 1955, 13).

Pro Mirošov je v pramenech k roku 1662 uvedena dvojice pustých rybníků, které naznačují existenci dvoustupňové rybniční soustavy. Dvě hráze zaniklých rybníků, jež se v terénu podařilo lokalizovat v údolí Smolinky a jejího bezejmenného přítoku, s nimi můžeme s velkou mírou pravděpodobnosti ztotožnit. Archeologicky zkoumaný prostor v bočním údolí patřil nejspíše menšímu rybníku sloužícímu $\mathrm{k}$ chovu potěru, případně mohl plnit funkci tzv. výtažníku. Pomocí geofyzikálního průzkumu se podařilo dokumentovat hráz rybníka a určit jeho přibližný rozsah. Celková plocha dosahuje ca 0,17 ha. Jen velmi rámcově jsme ale schopni interpretovat anomálie v blízkém okolí rybníka (kumulují se především kolem rybníka, zatímco na původně zatopené ploše absentují). Ty dokládají př́itomnost zahloubených objektů a stejně jako spektrum dalších drobnějších anomálií indikují blíže nespecifikované antropogenní aktivity. Jejich absence na původní ploše rybníka také vylučuje, že se jedná o drobný recentní odpad, který se na plochu dostal v období, kdy již rybník neplnil svou funkci, a byl zanesen sedimenty.

Obě odkrytá koryta, u nichž bylo dokumentováno rozpojení a poměrně značná vzdálenost jejich čel (ca $170 \mathrm{~cm}$, viz také obr. 7), musela být v minulosti těsně spojena. Možnost, že by mezi nimi ležel další, obdobný prvek, který by beze stopy zmizel (rozpadl se či byl vyzvednut), lze vzhledem k dobrému stavu ostatních dřev vyloučit. Pravděpodobnější je, že došlo ke svahové deformaci, která způsobila rozpojení obou prvků a zánik vlastního rybníka. Svahové deformace jsou v oblasti velmi běžné (Pánek a kol. 2010) a v tomto př́padě mohly být vyvolány samotnou konstrukcí rybníka. Stratigraficky se svahová deformace projevuje narušením vrstev mezi oběma dřevěnými koryty. Vrstva č. 5 (profil 8) může souviset i s opravou zařízení, v rámci které bylo nutno vyhloubit př́ístup ke korytu č. 1. Dřevěný prvek vyzvednutý z výkopu a datovaný do roku 1536/1537 může svědčit o snaze obnovit funkčnost rybníka v období vlády pánů z Lomnice. 


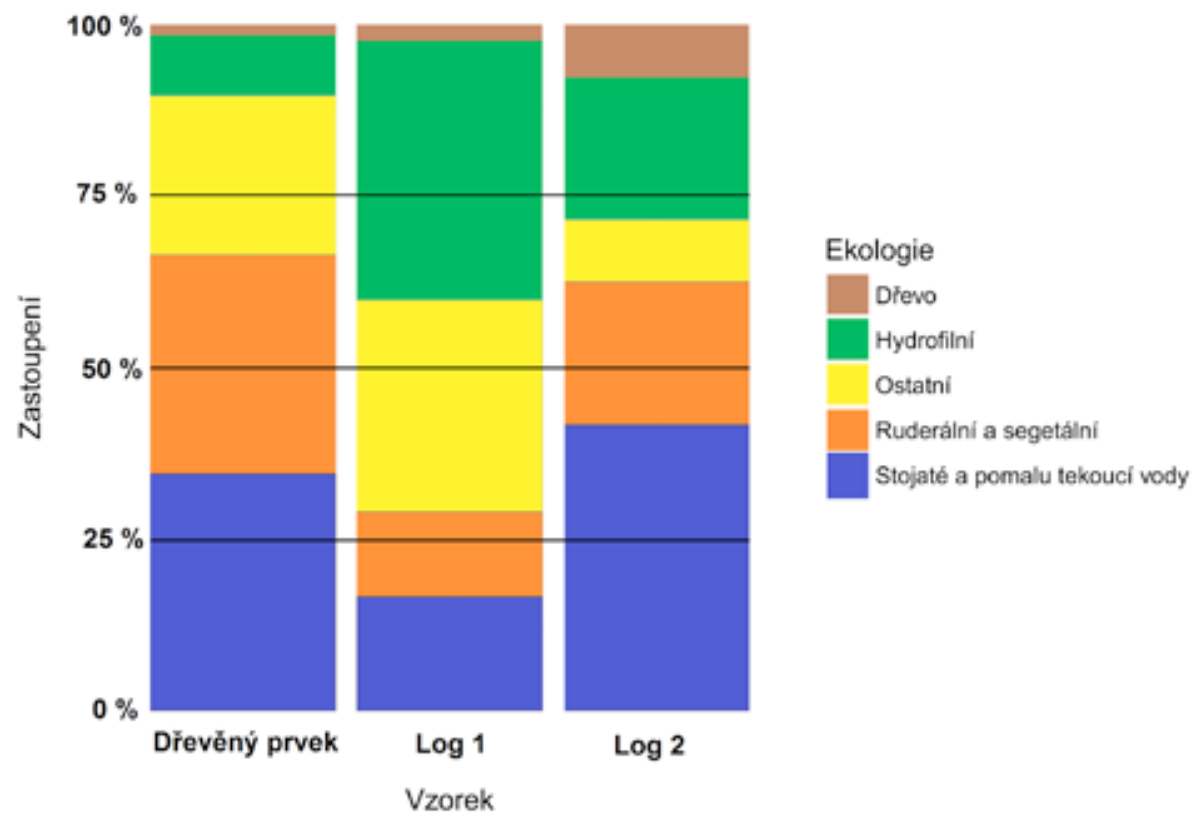

Obr. 13. Relativní zastoupení ekologických skupin rostlin zachycených analýzou rostlinných makrozbytků.

Abb. 13. Relatives Vorkommen der anhand einer Analyse der Pflanzenmakroreste erfassten ökologischen Pflanzengruppen.

V prostoru zaniklého rybníka byly v hloubce 410 až $370 \mathrm{~cm}$ a 410 až $260 \mathrm{~cm}$ zachyceny sedimenty aluvia malé vodoteče. Rozdílné mocnosti sedimentů pravděpodobně svědčí o založení hráze pod úrovní tehdejšího terénu. Hráz tedy byla ve shodě s dobovými doporučeními (viz Míka 1955, 28) zahloubena. Materiál vlastní hráze i sedimentů uložených v prostoru rybníka je v prostoru hráze (vzorkovací bod 1) a v prostoru výplně rybníka (vzorkovací bod 2) zrnitostně i dalšími parametry velmi podobný. To naznačuje, že při její konstrukci byly užity nejbližší dostupné sedimenty z blízkého okolí. Možná je také redepozice materiálu z rybničního dna na vnější části hráze. K tomu mohlo docházet během čištění rybníka a účelem mohlo být zpevnění již existujícího tělesa hráze. Jemné sedimenty rybníka odpovídají pomalému ukládání v klidném prostředí. To je však v prŕimém kontrastu se svrchními vrstvami, které svědčí o relativně rychlé akumulaci materiálu.

Makrozbytky v aluviu předcházejícímu založení rybníka ukazují na podobné ekologické spektrum jako jeho vlastní výplň, chybí pouze druhy stojatých vod. V místě založení vodního díla tak můžeme předpokládat člověkem odlesněnou krajinu s ruderální vegetací. Hráz je $\mathrm{v}$ dokumentovaném profilu zrnitostně a zejména spektrem makrozbytků identická se sedimenty rybníka. Zachycené makrozbytky rostlin indikují vodní prostředí a nemohly růst v prostředí hráze. To podporuje hypotézu, že vnější část hráze byla pokryta sedimenty z rybničního dna. Makrozbytkový záznam z výpusti stavidla se projevil jako zdaleka nejbohatší, což je dáno tafonomickými podmínkami, kdy při proudění vody docházelo $\mathrm{k}$ unášení lehkého rostlinného materiálu. Dalším důvodem mohlo být i tzv. letnění rybníka, kdy dno poroste efemérní vegetací, jež produkuje množství semen.

Pylový záznam ze sedimentů rybníka ukazuje již z valné části odlesněnou krajinu s výrazným výskytem pionýrských dřevin indikujících výrazné antropogenní narušení lesů. Jde o borovice (Pinus) nebo břízy (Betula), ale ve velké míře také lísku (Corylus), která je typická 
spíše pro mladší a střední holocén, tzn. období před expanzí buku (Fagus) a jedle (Abies). To je v kontrastu s původní vegetací na lokalitě Královec (Rybníčková-Hájková-Rybníček 2005) nedaleko města Valašské Klobouky, kde původně rostly bukové a jedlové lesy, přičemž fáze odlesnění je radiokarbonově datována do rozmezí mezi 12. až 15. století. Tehdy zde došlo k ústupu jedle (Abies), buku (Fagus) a dubu (Quercus) a naopak expandoval smrk (Picea), borovice (Pinus) a částečně líska (Corylus). To částečně odpovídá spektru dřevin jako líska (Corylus), topol (Populus) a dub (Quercus), které byly zachyceny ve formě úlomků z rybničního sedimentu v Mirošově. Toto spektrum ukazuje, že v blízkém okolí rybníka byla jen sekundární lesní vegetace. V mladším holocénu nejsou přirozené dřevinné dominanty, jimiž jsou buk (Fagus) či jedle (Abies), v makrozbytkovém záznamu rybníka zachyceny. Zajímavé je druhové zastoupení u dřevěných konstrukčních prvků rybníka, v nichž dominuje jedle (Abies), dub (Quercus) je zachycen pouze ve dvou prvcích. Bříza (Betula) coby pionýrská dřevina byla využita i na výplety okolo výpusti. To ukazuje na užití dřeva z nejbližšího okolí lokality. Zajímavým poznatkem je srovnání s recentním pylovým spadem, které ukazuje na zhruba podobný rozsah odlesnění jako v současnosti, ačkoliv ve středověku byla krajinná mozaika a způsob hospodaření odlišný než dnes. Také srovnání s blízkou lokalitou Královec ukazuje na podobný podíl pylů travin, obilovin a ruderálních taxonů, jako je tomu v Mirošově. Nález pylu přadných rostlin také ukazuje na vedlejší funkci nádrže, která mohla sloužit jako močidlo lnu či konopí.

Makrozbytkový záznam ukazuje silně ruderalizové okolí rybníka. Bezprostřední okolí rybníka bylo intenzivně narušováno, což naznačuje př́itomnost pěši komunikace na hrázi rybníka. Bohatě vyvinutá je litorální vegetace jako rdesno červivec (Polygonum persicaria), zajímavý je i výskyt ostřice české (Carex bohemica), která je typická pro obnažené písčité břehy a vypuštěná dna rybníků, těžištěm jejího rozšíření jsou rybniční oblasti (Řepka-Grulich 2014). Z Valašska recentně známa není. Dále jsou doloženy některé druhy stojatých vod, jako je rdest (Potamogeton) nebo okřehek (Lemna). Zcela minimální výskyt zelených řas r. Pediastrum, které indikují stojatou vodu, byl pravděpodobně způsoben průtočností rybníka.

\section{Závěr}

Archeologický výzkum pozůstatků rybničního díla nedaleko Mirošova vedl k lokalizaci sypané rybniční hráze, dřevěných konstrukčních prvků a fragmentů středověké keramiky. Nejstarší písemné zmínky o rybníkářství na brumovském panství jsou z roku 1539, avšak datum získané dendrochronologickým datováním dřevěných konstrukčních prvků rybníka posunuje doklady budování rybniční sítě již do období po roce 1488, kdy panství patřilo pánům Podmanickým. Rybník zanikl pravděpodobně narušením hráze svahovou deformací nejdřive po roce 1536. Průzkum širšího okolí archeologicky zkoumaného rybníka prokázal, že jeho pozůstatky souvisejí s dalšími identifikovanými stř̌edověkými a časně novověkými terénními relikty, především se sítí stř̌edověkých a novověkých úvozů a hrází dalšího rybníka. Doložení dvou rybničních hrází, které pravděpodobně odpovídají dvěma zaniklým rybníkům uvedeným v listině z roku 1662, ukazuje na př́tomnost dvoustupňové rybniční soustavy.

Hráz archeologicky zkoumaného rybníka byla nejspíše založena pod úrovní tehdejšího terénu. Sedimenty v jeho prostoru dokládají sedimentaci v klidném vodním prostředí a jejich přítomnost na vnější straně hráze pravděpodobně souvisí s údržbou rybníka, jak o tom svědčí i zbytky vodních rostlin, které zde byly nalezeny. Po zániku rybníka došlo v prostoru k masivní akumulaci další zeminy.

Paleoekologická analýza sedimentů rybníka doložila krajinu tvořenou mozaikou lesů, polí a pastvin, podobnou jako $\mathrm{v}$ současnosti. V prostoru rybníka byly zaznamenány zbytky vodní a segetální vegetace.

Dnes již neexistující rybníky na brumovském panství (listina z roku 1662 jich jmenuje dvacet šest) byly nesporně důležitou součástí zdejšího hospodářství a krajiny již od konce 15 . století. Počátek jejich úpadku lze pak vztáhnout nejspíše k válečným událostem 17. století, s nimiž by mohl být spjat i definitivní zánik rybniční soustavy v Mirošově. I po opuštění původní funkce 
Jan Petřík - Michal Hlavica - Libor Petr - Tomáš Chmela - Zdenek Schenk - Hana Lukšíková - Peter Milo - Radim Vrla - Petr Odehnal - Zdeněk Petrůj - Martin Petrůj - Petr Kočár: Rybník jako součást hospodářství vrchnostenského panství a indikátor podoby krajiny jižního Valašska v 15. až 17. století

však tato díla nepřestala být důležitým svědkem proměn př́rodního prostředí v jejich bezprostředním okolí a napomáhají tak upřesnit obraz o hospodaření v krajině na přelomu středověku a novověku na území jižního Valašska. Získané poznatky jsou nejen zásadní z hlediska poznání minulosti někdejšího brumovského panství, ale ilustrují také př́nos bádání nad zaniklými rybničními díly, jež byla po staletí běžnou součástí mnoha evropských regionů.

Tato práce byla podpořena grantem Masarykovy univerzity číslo MUNI/M/1790/2014 a vznikla ve spolupráci s Univerzitou Karlovou v rámci programu PROGRES Q09: Historie - Klíč k pochopení globalizovaného světa.

\section{Literatura}

ASTON, M., 1988: Aspects of fishpond construction and maintenance in the 16th and 17th centuries. In: Medieval Fish, Fisheries and Fishponds in England. Vol. 1-2. British Archaeological Reports 182 (Aston, M., ed.), 187-202. Oxford.

BARTÍK a kol., 2016: Bartík, J.-Chrástek, T.-Běhounková, L.-Rašticová, B.-Nohálová, H.-Novotný, J.Vavrčík, H., Středověké opevnění Uherského Hradiště ve světle archeologického výzkumu v ulici Dlouhá, Slovácko 57, 79-118.

BARTLOVÁ, M.-ČORNEJ, P., 2007: Velké dějiny zemí Koruny české VI. 1437-1526. Praha - Litomyšl.

BŮŽEK, V., 2010: Společnost českých zemí v raném novověku: struktury, identity, konflikty. Praha.

CAPPERS, R. T. J.-BEKKER, R. M.-JANS, J. E. A., 2006: Digital Seed Atlas of the Netherlands, Eelde [online]. Dostupné z http://seeds.eldoc.ub.rug.nl/, cit. 31. 1. 2016.

DOHNAL, V., 1977: Kultura lužických popelnicových polí na východní Moravě. Fontes Archaeologiae Moraviae 10. Brno.

DUBRAVIUS, J., 1559: De Piscinus et Piscium qui in eis aluntur naturis libri quinque, ut doctissimi, ita ad rem familiarem augendam utilissimi, ad illustrem virum Antonum Fuggerum. Dostupné z https://books. google.cz/books?vid=NKP:1002303235\&printsec $=$ frontcover\& $\mathrm{hl}=\mathrm{cs} \# \mathrm{v}=$ onepage \&q\&f=false.

HALAČKA, I., 1988: Mince zemí Koruny české. 2. díl. Kroměříž.

HEIRI, O.-LOTTER, A. F.-LEMCKE, G., 2001: Loss on ignition as a method for estimating organic and carbonate content in sediments: reproducibility and comparability of results, Journal of Paleolimnology 25, 101-110. DOI: 10.1023/A:1008119611481

HOFFMANN, R. C., 1996: Economic Development and Aquatic Ecosystems in Medieval Europe, The American Historical Review 101(3), 631-669. DOI: 10.2307/2169418

HURT, R., 1960: Dějiny rybnikářství na Moravě a ve Slezsku. I-II. Ostrava.

CHAMBERS, R. A., 1975: 'Three Fishponds at Thame', Oxoniensia 40, 238-246.

CHAMBERS, R. A.-GRAY, M., 1988: The excavation of fishponds. In: Medieval Fish, Fisheries and Fishponds in England. Vol. 1-2. British Archaeological Reports 182 (Aston, M., ed.), 113-135. Oxford.

JANKOVSKÁ, V.-POKORNÝ, J., 2002: Palaeoecology of a medieval fishpond system (Vajgar, Czech Republic), Folia Geobotanica 37(3), 253-273. DOI: 10.1007/BF02805211

KAMENÍČEK, F., 1902: Zemské sněmy a sjezdy moravské II. Brno.

KATZ, N. Ja.-KATZ, S. V.-KIPIANI, M. G., 1965: Atlas and keys of fruits and seeds occuring in the quaternary deposits of the USSR. Moscow.

KNITTLER, H., 2005: Teiche als Konjunkturbarometer? Das Beispiel Niederösterreich. In: Water Management in Medieval Rural Economy, RURALIA 5, 208-221.

KNOWLES, D., 1950: The Monastic Order in England. Cambridge.

KOLÁŘ, T.-KYNCL, T.-RYBNÍČEK, M., 2012: Oak chronology development in the Czech Republic and its teleconnection on a European scale, Dendrochronologia 30, 243-248. DOI: 10.1016/j.dendro.2012.02.002

MACEK, J., 1992: 1. Hospodářská základna a královská moc. Jagellonský věk v českých zemích (14711526). Praha.

MACŮREK, J.-REJNUŠ, M., 1958: České země a Slovensko ve století před Bílou horou. Praha.

MARTÍNEK, J.-LÉTAL, A.-MIŘIJOVSKÝ, J.-ŠLÉZAR, P.-VÍCH, D.-KALÁBEK, M., 2014: Poznáváme staré cesty. Brno.

MÍKA, A., 1955: Slavná minulost českého rybnikářství. Praha.

MOORE, P. D.-WEBB, J. A.-COLLINSON, M. E., 1991: Pollen analysis. 2nd ed. Oxford. 
ODEHNAL, P., 2000: Měšt’ané a předměšt'ané klobučtí. Příspěvek k poznání hospodářských poměrů poddaných na brumovském panství ve druhé polovině 16. století na základě rozboru pozemkových knih, ČMM CXIX, 45-64.

- 2007: „K většímu zlepšení statků našich“. Příspěvek k poznání formování městeček a měst na základě materiálu z Valašských Klobouk, Brumova a Vlachovic, ČMM CXXVI, 63-82.

- 2014: Nad hospodařením poddaných na jihovýchodní Moravě ve stínu válečných událostí 17. a počátku 18. století. In: Valašsko - historie a kultura (Urbanová, S.-Dokoupil, L.-Ivánek, J.-Kadlec, P., edd.), 165-174. Ostrava.

PÁNEK, T. a kol., 2010: Pánek, T.-Hradecký, J.-Minár, J.-Šilhán, K., Recurrent landslides predisposed by fault - induced weathering of flysch in the Western Carpathians. In: Weathering as a Predisposing Factor to Slope Movements (Calcaterra, D.-Parise, M., edd.), 183-199. London. DOI: 10.1144/EGSP23.11

POKLUDA, Z., 1999: Držitelé hradu Brumova, Zlínsko od minulosti k současnosti, 39-40.

- 2005: Brumov - osudy hradu a jeho držitelů. Hýsly.

POKORNÁ, A. a kol., 2014: Pokorná, A.-Houfková, P.-Novák, J.-Bešta, T.-Kovačiková, L.-Nováková, K.-Zavřel, J.-Starec, P., The oldest Czech fishpond discovered? An interdisciplinary approach to reconstruction of local vegetation in mediaeval Prague suburbs, Hydrobiologia 730(1), 191-213. DOI: 10.1007/s10750-014-1837-1

RYBNÍČKOVÁ, E.-HÁJKOVÁ, P.-RYBNÍČEK, K., 2005: The origin and development of spring fen vegetation and ecosystems - palaeogeobotanical results. In: Ecology and palaeoecology of spring fens of the West Carpathians (Poulíčková, A.-Hájek, M.-Rybníček, K., edd.), 29-60. Olomouc.

ŘEPKA, R.-GRULICH, V., 2014: Ostřice České republiky. Praha.

SHACKLEY, M.-HAYNE, J.-WAINWRIGHT, N., 1988: Environmental analysis of medieval fishpond at Owston abbey, Liecestershire. In: Medieval Fish, Fisheries and Fishponds in England. Vol. 1-2. British Archaeological Reports 182 (Aston, M., ed.), 301-308. Oxford.

SCHNITTER, N. J., 1994: A history of Dams. Rotterdam.

SKATULA, L., 1952: Vodní nádrže a jejich využití v lesnictví. Část III. Praha.

SKUTIL, J., 1937-1938: Paleolitické nálezy z Valašsko-Kloboucka, Naše Valašsko 4, 210-217.

ŠVÁBOVÁ, B., 2016: Vývoj profilu Drnovice v historické době. Praha.

TEPLÝ, F., 1937: Př́íspěvky k dějinám českého rybnikářství. Praha.

TEPLÝ, J., 2008: Příspěvek k dějinám rybníků a rybníkářství v předhusitském Chrudimsku. In: Theatrum historiae: sborník prací Katedry historických věd Fakulty filozofické Univerzity Pardubice, 9-45. Pardubice.

VÁLKA, J., 1991: Dějiny Moravy 1. Středověká Morava. Brno.

VOREL, P., 2005: Velké dějiny zemí Koruny české VII. 1526-1618. Praha - Litomyšl.

\section{Zusammenfassung}

\section{Fischteiche als ökonomische Bestandteile einer adeligen Grundherrschaft und als Indika- tor für die Landschaftsform der Mährischen Südwalachei im 15. bis 17. Jahrhundert}

Ziel der hier vorgelegten Studie ist es, Erkenntnisse über die Rolle der Teichwirtschaft in der regionalen Wirtschaft der Grundherrschaft Brumov zu gewinnen, die angewandten Verfahren der Fischzucht zu rekonstruieren sowie die Umweltdaten zu analysieren, die in den Sedimenten eines Fischteiches ab Ende des Mittelalters und Anfang der Neuzeit erhalten geblieben sind. Das Problem wird in verschiedenen räumlichen Maßstäben untersucht, angefangen bei der Wirtschaft und Regionalgeschichte der Grundherrschaft über die Auswertung von mittelalterlichen und frühneuzeitlichen Geländerelikten und archäologischen Funden aus dem ausgewählten Landschaftsabschnitt bis hin zu den technologischen Spezifika der konkreten, archäologisch untersuchten Teichanlage. Durch die Untersuchung der sedimentären Füllung versuchen wir auch den Zustand der im Süden der Mährischen Walachei gelegenen Landschaft in den unruhigen Zeiten an der Wende vom Mittelalter zur Neuzeit zu rekonstruieren. Die gesteckten Ziele wurden mittels Recherchen in den schriftlichen Quellen bezüglich der Bewirtschaftung der Grundherrschaft Brumov sowie durch eine archäologische Auswertung eines bisher unbekannten verschwundenen Fischteiches im Kataster der Gemeinde Mirošov erfüllt. 
Jan Petřík - Michal Hlavica - Libor Petr - Tomáš Chmela - Zdenek Schenk - Hana Lukšíková - Peter Milo - Radim Vrla - Petr Odehnal - Zdeněk Petrůj - Martin Petrůj - Petr Kočár: Rybník jako součást hospodářství vrchnostenského panství a indikátor podoby krajiny jižního Valašska v 15. až 17. století

Durch die archäologische Untersuchung der Überreste einer in der Nähe von Mirošov gelegenen Teichanlage konnte ein aufgeschütteter Teichdamm und Bauelemente aus Holz lokalisiert und mittelalterliche Keramikfragmente geborgen werden. Die ältesten schriftlichen Erwähnungen einer Teichwirtschaft in der Grundherrschaft Brumov stammen aus dem Jahr 1539, jedoch verschiebt das durch eine dendrochronologische Datierung der Bauelemente des Teiches ermittelte Datum die Belege für den Bau eines Teichnetzes bereits in die Zeit nach 1488 als die Grundherrschaft den Herren Podmanicky gehörte. Der Teich verschwand wahrscheinlich nach 1536 infolge einer durch einen Erdrutsch verursachten Störung des Dammes. Durch eine Untersuchung der breiteren Umgebung des archäologisch untersuchten Teiches wurde nachgewiesen, dass seine Überreste mit weiteren identifizierten mittelalterlichen und frühneuzeitlichen Geländerelikten zusammenhängen, vor allem mit einem mittelalterlichen und neuzeitlichen Hohlwegnetz und mit dem Damm eines weiteren Teiches. Der Nachweis der zwei Teichdämme, die wahrscheinlich zwei in einer Urkunde aus dem Jahr 1662 aufgeführten, verschwundenen Teichen entsprechen, deutet auf das Vorhandensein eines mehrstufigen Teichsystems hin.

Der Damm des archäologisch untersuchten Teiches wurde wahrscheinlich unterhalb des damaligen Geländeniveaus angelegt. Die in seinem Bereich vorhandenen Sedimente belegen eine Sedimentierung in einer ruhigen Wasserumgebung, und ihr Vorhandensein an der Dammaußenseite hängt wahrscheinlich mit der Wartung des Teiches zusammen, worauf auch die dort vorgefundenen Wasserpflanzenreste hindeuten. Nachdem der Teich verschwunden war ist es in diesem Bereich zu einer massiven Anhäufung weiterer Böden gekommen. Durch die paläoökologische Analyse der Teichsedimente wurde eine Landschaft belegt, die aus einem Mosaik aus Wäldern, Feldern und Weiden bestand und mit der heutigen vergleichbar ist. Im Bereich des Teiches wurden Reste einer Wasser- und Segetalvegetation verzeichnet.

Abschließend kann man festhalten, dass die heute bereits nicht mehr existierenden Teiche in der Grundherrschaft Brumov (in einer Urkunde aus dem Jahr 1662 werden sechsundzwanzig von ihnen aufgeführt) zweifellos bereits ab dem Ende des 15. Jahrhunderts Bestandteile der dortigen Wirtschaft und Landschaft waren. Die Anfänge ihres Niedergangs kann man dann höchstwahrscheinlich zu den Kriegsereignissen des 17. Jahrhunderts in einen Bezug setzen, mit denen auch der definitive Untergang des Teichsystems in Mirošov verbunden sein kann. Nach Aufgabe ihrer ursprünglichen Funktion sind diese Anlagen auch weiterhin ein wichtiges Zeugnis für die Veränderungen der Umwelt in ihrer unmittelbaren Umgebung und tragen dazu bei, das Bild von der Bewirtschaftung in dieser Landschaft an der Wende vom Mittelalter zur Neuzeit in dem südlich gelegenen Gebiet der Mährischen Walachei zu präzisieren. Die gewonnenen Erkenntnisse sind nicht nur im Hinblick darauf wesentlich, die Vergangenheit der einstigen Grundherrschaft Brumov kennenzulernen, sondern illustrieren auch den Beitrag der Erforschung von verschwundenen Teichanlagen, die über Jahrhunderte hinweg gängige Bestandteile vieler europäischer Regionen waren.

Die vorliegende Arbeit wurde durch das Förderprojekt der Masaryk-Universität Nr. MUNI/M/1790/2014 und durch das Förderprojekt der Karls-Universität PROGRES Q09: Geschichte - Schlüssel zum Verständnis der globalisierten Welt, gefördert.

Jan Petřík, Ústav geologických věd Př́írodovědecké fakulty Masarykovy univerzity, Kotlářská 2, a Ústav archeologie a muzeologie Filozofické fakulty Masarykovy univerzity, Arna Nováka 1, 60200 Brno, Česká republika,petrik.j@mail.muni.cz

Michal Hlavica, Ústav archeologie a muzeologie Filozofické fakulty Masarykovy univerzity, Arna Nováka 1, 60200 Brno, Česká republika, hlavica@phil.muni.cz

Libor Petr, Ústav botaniky a zoologie Př́rodovědecké fakulty Masarykovy univerzity, Kotlářská 2, 60200 Brno, Česká republika,petr.libor@gmail.com 
Tomáš Chmela, Ústav pro archeologii Filozofické fakulty Univerzity Karlovy, nám. Jana Palacha 2, 11636 Praha, Česká republika,Tomas.Chmela@seznam.cz

Zdeněk Schenk, Muzeum Komenského v Přerově, p. o., Horní náměstí 7/7, 75002 Přerov I-Město, Česká republika,schenk@prerovmuzeum.cz

Hana Lukšíková, Ústav archeologie a muzeologie Filozofické fakulty Masarykovy univerzity, Arna Nováka 1,60200 Brno, Česká republika, hana.luksikova@gmail.com

Peter Milo, Ústav archeologie a muzeologie Filozofické fakulty Masarykovy univerzity, Arna Nováka 1, 60200 Brno, Česká republika, 101090@mail.muni.cz

Radim Vrla, Národní památkový ústav, územní odborné pracoviště v Kroměřǐži, Sněmovní náměstí 1, 76701 Kroměříž, Česká republika, vrla.radim@npu.cz

Petr Odehnal, Městské muzeum Valašské Klobouky, Masarykovo náměstí 276, 76601 Valašské Klobouky, Česká republika, odehnal.muzeum@volny.cz

Zdeněk Petrůj, Smolina 9, 76601 Valašské Klobouky, Česká republika

Martin Petrůj, Masarykovo náměstí 182, 76601 Valašské Klobouky, Česká republika

Petr Kočár, Archeologický ústav AV ČR, Praha, v. v. i., Letenská 4, 11801 Praha 1, Česká republika, kocar@arup.cz 
